San Jose State University

SJSU ScholarWorks

Master's Theses

Master's Theses and Graduate Research

1989

\title{
Temporal and spatial variations in salt pond environments and implications for fish and invertebrates
}

David George Lonzarich

San Jose State University

Follow this and additional works at: https://scholarworks.sjsu.edu/etd_theses

\section{Recommended Citation}

Lonzarich, David George, "Temporal and spatial variations in salt pond environments and implications for fish and invertebrates" (1989). Master's Theses. 3087.

DOI: https://doi.org/10.31979/etd.d6cb-ec42

https://scholarworks.sjsu.edu/etd_theses/3087

This Thesis is brought to you for free and open access by the Master's Theses and Graduate Research at SJSU ScholarWorks. It has been accepted for inclusion in Master's Theses by an authorized administrator of SJSU ScholarWorks. For more information, please contact scholarworks@sjsu.edu. 


\section{INFORMATION TO USERS}

The most advanced technology has been used to photograph and reproduce this manuscript from the microfilm master. UMI films the text directly from the original or copy submitted. Thus, some thesis and dissertation copies are in typewriter face, while others may be from any type of computer printer.

The quality of this reproduction is dependent upon the quality of the copy submitted. Broken or indistinet print, colored or poor quality illustrations and photographs, print bleedthrough, substandard margins, and improper alignment can adversely affect reproduction.

In the unlikely event that the author did not send UMI a complete manuscript and there are missing pages, these will be noted. Also, if unauthorized copyright material had to be removed, a note will indicate the deletion.

Oversize materials (e.g., maps, drawings, charts) are reproduced by sectioning the original, beginning at the upper left-hand corner and continuing from left to right in equal sections with small overlaps. Each original is also photographed in one exposure and is included in reduced form at the back of the book. These are also available as one exposure on a standard 35mm slide or as a $17^{\prime \prime} \times 23^{\prime \prime}$ black and white phstographic print for an additional charge.

Photographs included in the original manuscript have been reproduced xerographically in this copy. Higher quality $6^{\prime \prime} \times 9^{\prime \prime}$ black and white photographic prints are available for any photographs or illustrations appearing in this copy for an additional charge. Contact UMI directly to order.

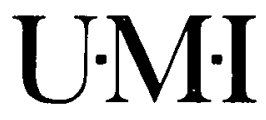

University Microfilms International

A Bell \& Howell Information Company

300 North Zeeb Road, Ann Arbor, MI 48106-1346 USA

$313 / 761-4700 \quad 800 / 521-0600$ 
Order Number 1397821

Temporal and spatial variations in salt pond environments and implications for fish and invertebrates

Lonzarich, David George, M.A.

San Jose State University, 1989

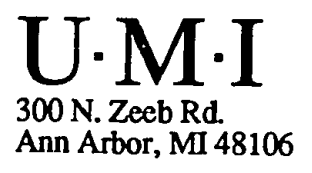




\title{
TEMPORAL AND SPATIAL VARIATIONS IN \\ SALT POND ENVIRONMENTS AND \\ IMPLICATIONS FOR FISH AND INVERTEBRATES
}

\author{
A Thesis \\ Presented to \\ The Faculty of the Department of Biological Sciences \\ San Jose Scate University
}

In Partial Fulfillment

of the Requirements for the Degree

Master of Arts

By

David George Lonzarich

May, 1989 

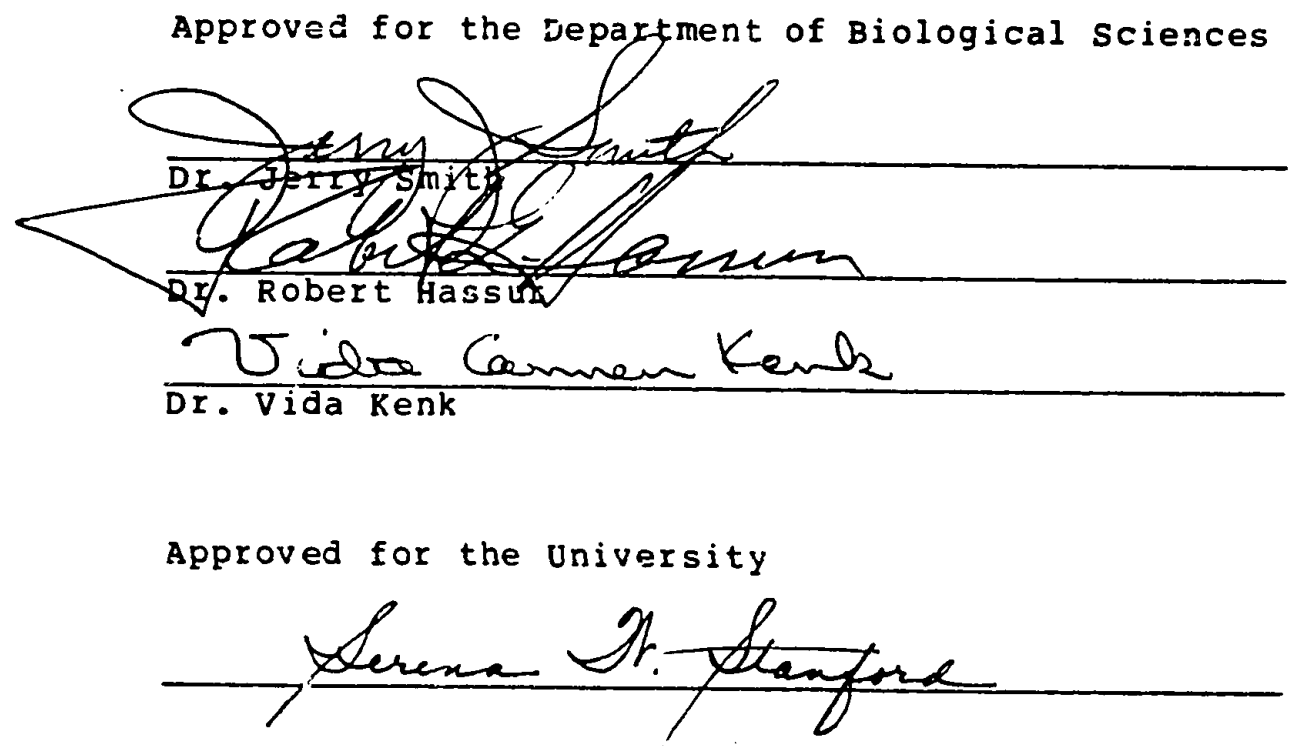


\begin{abstract}
I studied water quality and the distribution of aquatic species in a series of brackish and hypersaline (20-85 ppt) salt evaporation ponds in south San Francisco Bay between May 1985 and November 1986. Physical and chemical characteristics in the ponds were distinct from, and often more stressful than, the surrounding Bay. Invertebrate abundance varied substantially among ponds and seasons. Brine shrimp (Artemia salina) and copepods were the dominant invertebrates in high salinity ponds, whereas benthic and epibenthic invertebrates were most abundant in low salinity ponds. Slight changes in salinity in the range of $30-40$ ppt produced large changes in community composition.

Fifteen $f$ ish species were collected in the ponds. Six species were able to reproduce in some ponds, and topsmelt (Atherinops affinis) and longjawed mudsucker (Gillichthys mirabilis) were able to reproduce to 75 ppt salinity. The remaining nine species occurred as transients from the Bay.
\end{abstract}




\section{ACKNOKL EDGEMENTS}

I wish to express my sincerest gratitude to those who helped make this study possible, including the santa clara Audubon Society for their generous grant supporting my project, and Dr. Robert Hassur and the staff of the San Francisco Bay Bird Observatory for their guidance in the development phases of it. I am also grateful to the san Francisco Bay National wildlife Refuge and the Leslie salt Company for granting me access to their land, and the staff of San Jose State University for their technical assistance. Special thanks are extended to Peg Woodin, Judy Vandervere, Colleen Pelles, Valerie Layne, Javid Clanon, Mark Robinson and others who helped conduct the sometimes thankless field and laboratory work, and Dr. Vida kenk for providing her moral support and wisdom. I also wish to thank Dr. Kenk and Dr. Robert Hassur, Jean Takekawa and Jocelyn Aycrigg for their critical review of the manuscript.

Finally, I thank my faculty advisor, Dr. Jerry Smith for demanding the most from me, and being a friend when I needed one most. 
TABLE OF CONTBNTS

Page

\begin{abstract}
. . . . . . . . . . . . . . . . . . . . . . i i
ACRNOWLEDGEMENTS • • • • • • • • • • • • • • • • • • • • v

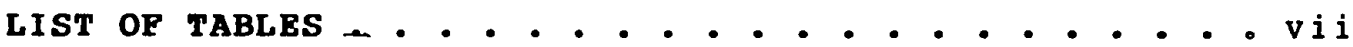

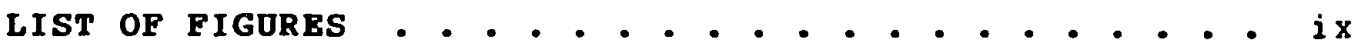

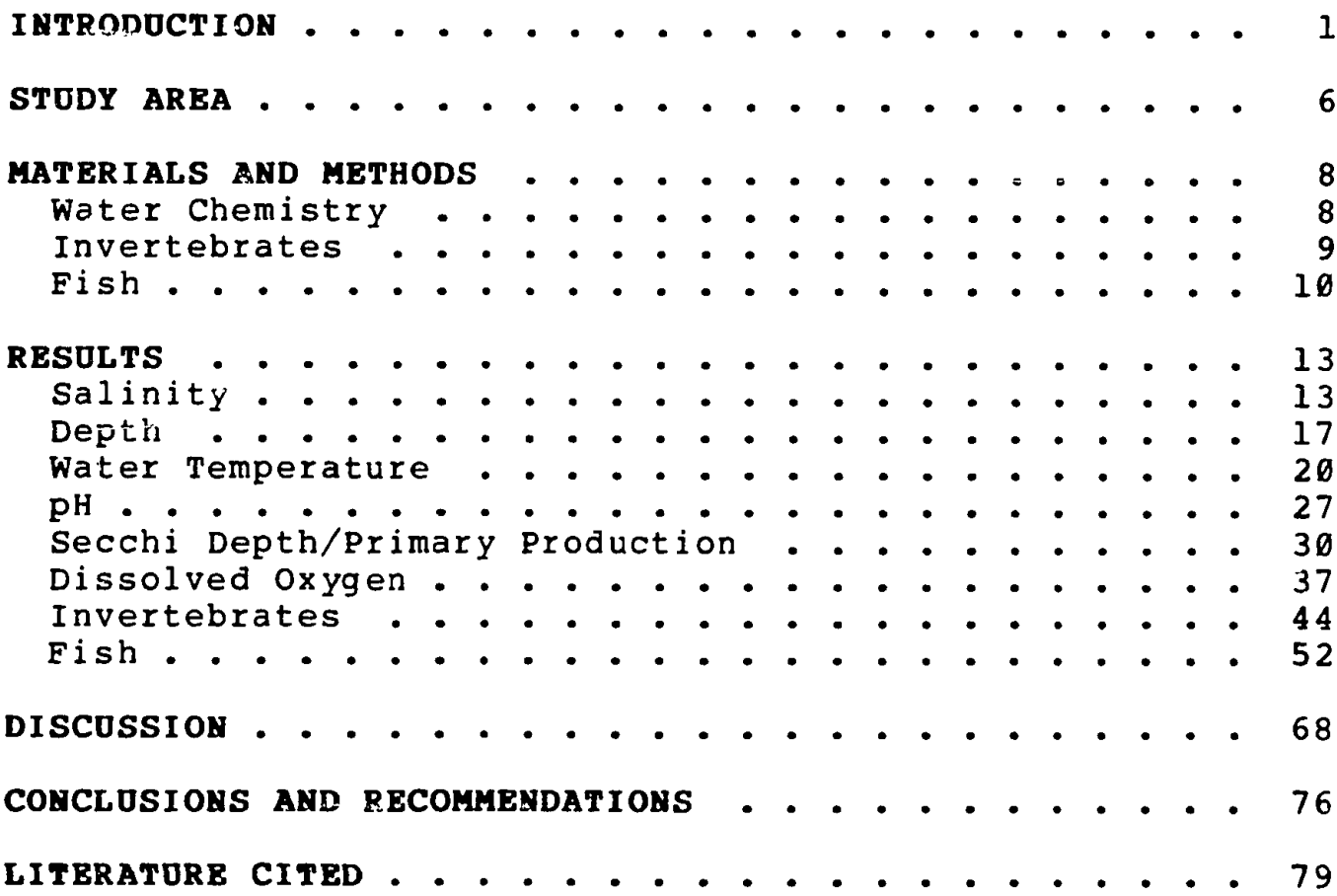




\section{LIST OF TABLBS}

Table

Page

1. Diurnal surface water temperatures at NS stations in Ponds $A 9$ and Al2 during seasonal samples .............. 26

2. Estimated percent surface cover for Enteromorpha in Ponds $A 9$ and $A 10$, for August 1985 to september 1986 . . . . . . . 36

3. Diurnal surface dissolved oxygen levels at NS stations in Ponds $A 9$ and Al2 during seasonal samples . . . . . . . . . . . . 39

4. Invertebrate species distribution in six Alviso salt evaporation ponds, 1985-86 . . . . 45

5. Seasonal patterns of abundance for invertebrate species collected from Pond A9. $r=$ rare; $u=$ uncommon; $c=$ common;

$a=$ abundant ..................446

6. Seasonal patterns of abundance for invertebrate species collected from pond Alb $\mathbf{r}=$ rare; $\mathrm{u}=$ uncommon; $\mathbf{c}=$ common; $a=$ abundant

7. Mean zooplankton biomass (g, dry wt.) and relative abundance of brine shrimp (Artemia salina) collected in surface plankton tows at NS stations in Alviso salt evaporation ponds. ( $n=2$ for each mean, except *, where only one sample was taken............

8. Distribution and status of $\mathrm{fish}$ species collected in Alviso salt evaporation ponds, 1985-86. Pond (salinity range in ppt. $R$ = resident population; $S=$ seasonal population; $J=$ juvenile only . . . 53

9. Catch per unit effort (mean \pm S.D.) for the four most common $f$ ish species collected in 24 hour gill net surveys from Alviso salt ponds from fall 1985 to fall 1986 .......

10. Standard lengths (mean \pm S.D.) of topsmelt collected by gill net in low and high salinity ponds from fall 1985 to fall 1986 ... 
11. Measurements of reproductive maturity in adult topsmelt ( $>100 \mathrm{~mm}$ ) collected from four high salinity ponds between February 1986 and october 1986 . Percent volume-gonads is gonda volume as percent of the total fish volume. Egg maturity was based on measurements of egg diameter, with 1 = immature eggs, $2=$ mature eggs, 3 = spent (after Shultz, 1933) . . 58

12. Diet of topsmelt (Atherinops affinis) from four high salinity poncis, and the relative availability of prey species (prey av.)

determined from plankton surveys

13. Diet of longjawed mudsucker (Gillichthys mirabilis) from four high salinity ponds, and the relative availability of prey species (prey av.) determined from plankton surveys . . 62 


\section{LIST OF FIGORES}

Figure

Page

1. Location of study area in south San

Francisco Bay and northshore stations (ns)

and southshore (ss) stations for study ponds

A9 - Al3, and Al5 . . . . . . . . . . .

2. Mean monthly surface salinities measured at NS stations in Alviso salt ponds from May 1985 to october 1986 ............ 14

3. Mean monthly depth measurements (cm) recorded at shoreline stations in Alviso salt ponds from May 1985 to November 1986

4. Mean monthly surface water temperatures measured at NS stations during morning in Alviso salt ponds from May 1985 to october 1986

5. Mean monthly maximum (solid line) and minimum (dashed line) surface water temperatures measured at NS stations during morning in Alviso salt ponds from August 1985 to september 1986 ......... 22

6. Mean monthly morning air (dashed line) and surface water (solid line) temperatures measured at NS station in Pond Al2 from May 1985 to october 1986 . . . . . . . . . 23

7. Morning (dashed line) and afternoon (solid line) temperature profiles from Pond Al 3 for seasonal sampling dates (a) 22 Jan 1986; (b) 22 Mar 1986; (c) 28 Jun 1986 (d) 22 Nov 1986 • . 24

8. Morning (dashed line) and afternoon (solid line) temperature profiles from Pond $A 9$ for seasonal sampling dates (a) 22 Jan $1986 ;$ (b) 22 Mar 1986; (c) 28 Jun 1986 (d) 22 Nov 1986

9. Morning NS station pH plotted against salinity in Alviso salt ponds from April 1985 to November $1986(r=-6.53)$...... 28

10. Mean monthly morning pH measured at NS stations in Alviso salt ponds from May 1985 to october 1986 
11. Secchi depth for Alviso salt ponds from March to September 1986. Note scale change . . 31

12. Monthly secchi depths plotted versus salinity in Alviso salt ponds (a) Pond A9; (b) Pond Alg; (c) Pond All; (d) Pond Al2;

(e) Pond Al3; (f) Pond Al5 ........... 33

13. Secchi depth versus salinity in four high salinity ponds (All - Al5) from March to september 1986 . . . . . . . . . . . . . .

14. Mean monthly dissolved oxygen levels at NS stations during morning in six salt ponds from May 1985 to October 1986 (a) Pond A9 (ns/ss); (b) Pond Alo; (c) Ponds All/Al2; (d) Ponds Al3/Al5 . . . . . . . . . 38

15. Morning and afternoon dissolved oxygen profiles from Pond Al3 for seasonal sampling dates (a) 22 Jan 1986; (b) 22 Mar $1986 ;$ (c) 28 Jun 1986 (d) 22 Nov 1986

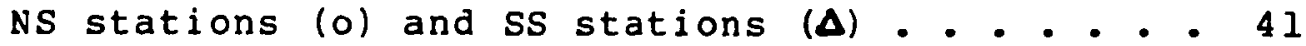

16. Morning and afternoon dissolved oxygen profiles from Pond A9 for seasonal sampling dates (a) 22 Jan 1986; (b) 22 Mar $1986 ;$ (c) 28 Jun 1986 (d) 22 Nov $1986 \ldots . . . .42$

17. Relative abundance of Artemia salina and copepods at different salinities in Alviso salt ponds between January and November 1986 • . 50

18. Relative growth rates in culture of predominant salt pond phytoplankton at different salinities ............. 73 


\section{ATRODUCTION}

over one century ago the south san Francisco Bay shoreline was bordered by many kilometers of salt marshes and mudflats that supported a diverse and productive flora and fauna. Since that time, however, the area of these wetlands has been steadily diminishing, and today less than 15 percent of the wetlands in south San Francisco Bay remain undeveloped (Nichols et al., 1986). Some of these marshes have been converted for agricultural, commercial, or residential purposes, but most have been diked for solar salt production. presently, the Leslie salt Company harvests Bay salt from over 18,000 hectares $(44,000$ acres) of solar salt evaporation ponds in San Francisco Bay, including over 13,600 hectares in south san Francisco Bay.

The loss of south San Francisco Bay wetland habitats has had immeasurable effects on many marsh dependent species, such as waterfowl, shorebirds, and the endangered California clapper rail (Rallus longirostris obsoletus) and salt marsh harvest mouse (Reithrodontomys raviventris raviventris). Although wetlands converted for agricultural use retained limited wildife value (Josselyn, 1983), the value to wildife of those wetlands converted for commercial or residential use is negligible. Salt ponds form a series 
of habitats, defined primarily by their salinity, which can range from brackish to highly concentrated brine. Bay water is diverted into intake ponds and circulates through a series of ponds, where salinity progressively increases by the process of solar evaporation. This process continues until the saturation point of sodium chloride is reached, at approximately ten times the concentration of sea water. The pond habitats created by these conditions are diverse and have: been exploited to varying degrees by many wetland species. The hypersaline salt ponds, in particular, provide a unique habitat type in San Francisco Bay that has permitted some species of birds not historically common in the Bay, or more typically associated with hypersaline lakes, to flourish (i.e., eared grebe (Podiceps nigricollis), black-necked stilt (Himantopus mexicanus), white pelican (Pelecanus spp.), California gull (Larus californicus), and caspian tern (Sterna caspia)) (Anderson, 1970; T. Harvey, USFWS, pers. comm.)

South San Francisco Bay salt ponds and their levees provide roosting, feeding, and nesting habitats for many species of waterbirds. Some of these species rely on the ponds only for specific uses (e.g., roosting), whereas others use the ponds almost exclusively (i.e., phalaropes (Phalaropus spp.), bonaparte gull (Larus philadelphia) and 
eared grebe). The great majority of the dabbling ducks (i.e., northern shoveler (Anas clypeata), northerr pintail (Anas acuta), and American wigeon (Anas americana)) in south San Francisco Bay roost or feed in the salt ponds, as do many diving ducks (i.e., ruddy duck (oxyura jamaicensis) (Takekawa et al., 1988). The ponds are also integral to the ecology of shorebirds in south san Francisco Bay. Of the several hundred thousand shorebirds that migrate through san Francisco Bay each winter, most feed in the tidal mudflats at low tides and roost or feed in the shallow water ponds during high tides (stenzel and Page, 1988).

Most biological studies conducted on San Francisco Bay salt ponds have had a very narrow focus, with the greatest emphasis placed on the biology of waterbirds (Gill, 1977; Anderson, 1970; Swarth et al., 1982; Howard, 1983) and brine shrimp (Artemia salina) (Berthelemy-okazaki, 1986; Baker, 1966; Swarth et al., 1982). The vast majority of the waterbird studies have been surveys which have focused on the distribution of wintering and breeding populations, but others, such as that conducted by swarth et al. (1982), attempted to explain the distribution of waterbirds with respect to salinity, prey availability, pond depth, and other environmental factors. In general, these studies demonstrated that pond salinity and depth greatly affect 
bird distribution patterns. Brine shrimp are the main component in the food chain of the hypersaline ponds (where salinities exceed $70 \mathrm{ppt}$ ). Despite a paucity of quantitative studies on bird feeding behavior (Howard, 1983), brine shrimp are undoubtedly a critical food source for waterbirds that feed in the ponds. Fish and invertebrates found in the ponds have seldom been studied, although it is apparent that salt pond fish provide a very important prey resource for many species of birds, including the endangered least tern (Feeney, pers. comm.). Carpelan (1957) conducted the only comprehensive study of the fish communities and physio-chemistry of south San Francisco Bay ponds. He found that topsmelt (Atherinops affinis) and long-jawed mudsucker (Gillichthys mirabilis) were widespread in the ponds below 70 ppt, but he found few other species even at lower salinities.

The primary purpose of this one and one-half year study (April 1985 - November 1986) was to describe the structure and dynamics of the fish communities of a series of six low to moderate salinity $(20-85 \mathrm{ppt})$ salt evaporation ponds in south San Francisco Bay near Alviso. Distribution patterns were compared to spatial and temporal variations in pond hydrology, invertebrate prey composition, and prey abundance. Age structure, breeding status, and feeding 
behavior of the most common $f$ ish species were also

investigated. The study is intended to provide a general

understanding of the ecology of the ponds under present

solar evaporation operations and also to provide a basis for

their potential management within the San Francisco Bay

National wildife Refuge should commercial solar evaporation

be abandoned. 


\section{STODY AREA}

The study area is located immediately north of Alviso in south San Francisco Bay (hereafter referred to as south Bay), and encompasses six salt ponds bounded to the north by Coyote Creek, to the southwest by Alviso Slough, and to the east by Southern Pacific railroad tracks (Fig. 1). Like other South Bay salt ponds, the Alviso ponds are large (ranging in size from 100 to 150 hectares) and shallow (mean depth less than 1 meter). The ponds in this unit are linked with the South Bay and the mouth of Alviso slough at Pond A9 through two, 1.2 meter diameter culverts located in the western levee adjacent to Alviso slough. When the culverts are open from late spring through late fall, brackish water from Alviso slough enters Pond $A 9$ at high tide and flows by gravity through a 1.2 meter diameter culvert into pond $\mathrm{Al0}$. From Pond $A 10$, the waier circulates through regulated culverts into Ponds All, A12, and A13. The water in Pond Al3 is typically pumped into Pond Al5, however, it may also be pumped into pond Al4, where it is stored until needed in Pond Al5. An additional intermittent source of water is Pond $A 8$, a high salinity pond located directly across from Pond All on the west edge of Alviso slough. A pipe under Alviso Slough diverts water from Pond A8 into Pond All. 


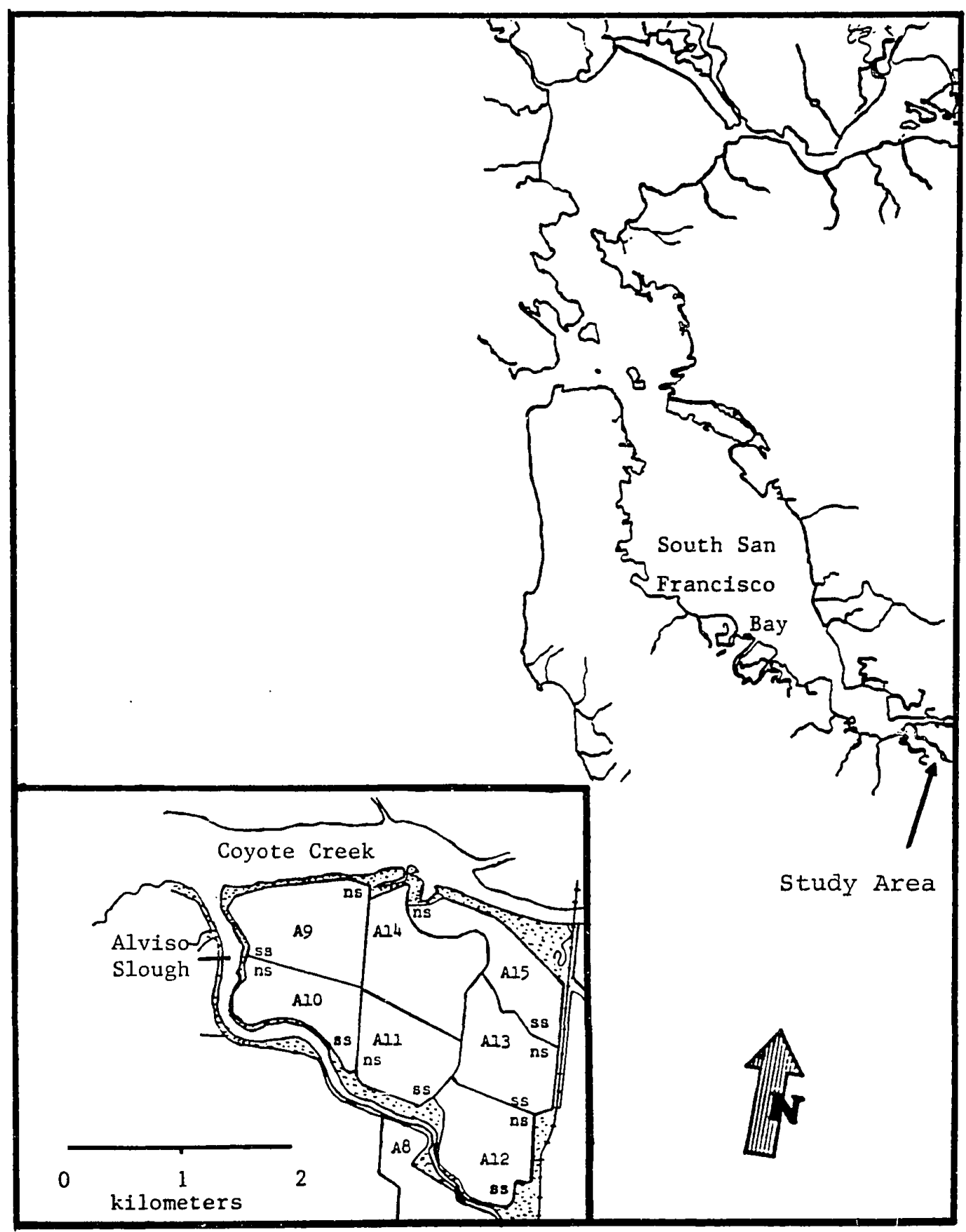

Figure 1: Location of study area in south San Francisco Bay and northshore (ns) and southshore (ss) stations for study ponds A9 - Al3 and Al5. 


\section{MATERIALS AND METHODS}

\section{Water Chemistry}

Water quality characteristics in the six ponds were measured at northshore (NS) and southshore (SS) monitoring sites between April 1985 and october 1986. Changes in water level were determined weekly from staff gauges in each pond. Measurements of surface salinity (American Optics Refractometer), dissolved oxygen (YSI model 54 Do meter), pH (Cole Parmer $\mathrm{pH}$ meter), and water temperature were made on site biweekly (weather permitting) through April 1986, then monthly through october 1986. Diurnal fluctuations in surface water temperature, dissolved oxygen, and $\mathrm{pH}$ were determined on one typical day every three months in Ponds A9 and Al2. Monthly pond surface temperatures ranges were also determined from permanently stationed maximum and minimum thermometers. Secchi depths were determined in the afternoon once a month from March 1986 through October 1986. Afternoon (1300-1600) water column profiles for dissolved oxygen, temperature, $\mathrm{pH}$, and salinity were examined in the six ponds seasonally from the fall of 1985 to the fall of 1986. Morning measurements ( $8800-1000)$ were made during the summer and fall of 1986 . 


\section{Invertebrates}

Benthic and epibenthic invertebrates were examined seasonally from the six ponds from the fall of 1985 to the fall of 1986 to determine general abundance of potential prey for fish. In Ponds $A 9$ and $A l \emptyset$, epibenthic invertebrates were removed from algal samples, which were collected by hand or dip net from the benthos, and stored in 4 percent formaldehyde. During each sampling period, two to three epibenthic and infauna samples were collected from Ponds $A 9$ and $A 1 \emptyset$, and one sample was collected from each of Ponds All-Al5 using an Eckman dredge $(21.2 \mathrm{~cm} \times 21.2 \mathrm{~cm})$. Sediment samples were stored on ice in the field and returned to the laboratory where they were sieved using a $0.5 \mathrm{~mm}$ sieve and stored in 4 percent formaldehyde. Specimens were later identified to order (Actiniaria, Copepoda and ostracoda), genus, or species (all other taxa). For Ponds $A 9$ and $A 10$, and for Ponds All-Al5 collectively, the taxa were ranked for general abundance as either abundant (numerous and collected at every site); common (moderately abundant, collected at every site); uncommon (moderately abundant not collected at every site) or rare (low numbers, not collected at every site).

Seasonal zooplankton surveys were conducted in each pond from December 1985 through November 1986. Two replicate 
surface plankton tows with an $0.30 \mathrm{~m}$ diameter net and 10 um mesh were made along $50 \mathrm{~m}$ transects in the borrow pits along the south shore margin of each pond. Plankton collected in the net were washed into specimen vials and fixed in 4 percent formaldehyde. In the laboratory, samples were washed with tap water to remove salt water, and oven dried at 50-60 C degrees for 24-48 hours. Total dry weight, species composition, and relative densities were then determined for each sample.

Fish

Fish were collected from the six ponds between the months of August 1985 and september 1986 by beach seine, minnow trap, and variable mesh gill net. Two beach seines were used. One measured $15.2 \mathrm{~m} \times 1.8 \mathrm{~m}$ with $0.95 \mathrm{~cm}$ square mesh and the second was a $30.5 \mathrm{~m} \times 1.8 \mathrm{~m}$ net with $0.5 \mathrm{~cm}$ square mesh. Although seining was generally effective, it was not suitable for every pond. In Ponds $A 9$ and $A i g$, for example, dense bottom vegetation and steep shorelines made seining difficult. By the spring of 1986, when macroalgal growth was highest, efforts to seine these two ponds were discontinued. The timing of seine surveys in Ponds All through Al.5 was irregular, although sampling was generally seasonal. Two to three samples were taken from each pond on 
each date.

Beginning in January 1986, minnow traps were added to improve collections of small pelagic and benthic species. Typically, two unbaited minnow traps were set for 24-48 hours in each pond. Sampling was conducted monthly in Ponds A9 and Alb, bimonthly in Pond All and seasonally in Ponds Al2 through AI5.

Large fish not collected by minnow trap and seines were collected with gill nets. Two net types were used in this study. One net measured $36.6 \mathrm{~m} \times 1.8 \mathrm{~m}$ with 2 panels of 1.2 $\mathrm{cm}$ and $1.9 \mathrm{~cm}$ square mesh, and the second was $38 \mathrm{~m} \times 1.8 \mathrm{~m}$ with 5 panels ranging from 1.2 to $5 \mathrm{~cm}$ square mesh. One or two nets were generally set in each pond for approximately 24 hours. Surveys were conducted monthly in Ponds A9 and Al0, bimonthly in Pond All, and seasonally in Ponds Al2 through A15. All individuals collected were measured to the nearest $\mathrm{mm}$ standard length (SL). Most of the fish collected were immediately released, but several individuals from each catch were preserved for subsequent determinations of feeding habits, age structure, and reproductive condition. Food habits were determined for the most abundant fish collected in the ponds. Samples were categorized by season and pond type, and 5-10 individuals were examined from each sample. Prey percent numbers, percent volume, and frequency 
of occurrence were recorded for the contents of the stomach and upper one-third of the intestine in each fish.

Age structure and growth rates of the most common $f$ ish species were determined by length frequency distributions and by aging and back calculations from scale annuli. Length frequency distributions were also used to document the spawning seasons. For topsmelt, two additional methods were used to evaluate reproductive maturity and spawning season. Gonad volume and total fish volume were measured and the percent of the total volume accounted for by the gonads in individual fish was calculated. The diameter of individual eggs was also determined and qualitatively ranked into three categories of development. Eggs were either immature/spent (range $\emptyset . \emptyset-\emptyset .4 \mathrm{~mm}$ ), maturing $(\emptyset .4-1 . \emptyset \mathrm{mm}$ ), or ripe $(>1.0 \mathrm{~mm}$ ) (as described by schuliz 1933). Biological results, including productivity and individual species abundances, were compared to environmental variables by correlation and multiple regression. 


\section{RBSOLTS}

\section{Salinity}

Figures $2 a-b$ show the mean monthly salinities measured at northshore sites in the six Alviso ponds. Salinities ranged from 20 ppt to more than $80 \mathrm{ppt}$. There was some overlap among ponds, but mean salinities in Ponds $A 9$ and $A l \theta$ were much lower and more stable than in Ponds All to Al5. Salinities in Pond $A 9$ and $A 10$ averaged 30 ppt, and ranged from brackish to slightly hypersaline $(2 \emptyset-4 \emptyset \mathrm{ppt})$. In Ponds All through A15, salinities were typically greater than 35 ppt and variable. Mean salinities in these ponds were from 50 to 68 ppt during the study and ranged from 23 ppt to 84 ppt. Seasonal changes in salinity were greatest in Pond All, which received low salinity water from pond $A l \emptyset$ and high salinity water from pond AB. Salinities in Pond All were 50 ppt higher than those in adjacent Pond $A I 0$ in January 1986 ( 84 vs 33 ppt), and well below sea water concentrations in september 1986 (23 ppt). Fluctuations in salinity within Ponds Al2, Al3, and Al5 were less extreme than those measured in pond All, but still varied by over 35 ppt over the course of the study.

within each pond there were slight, but detectable, gradients in salinity across ponds and with depth: Mean 

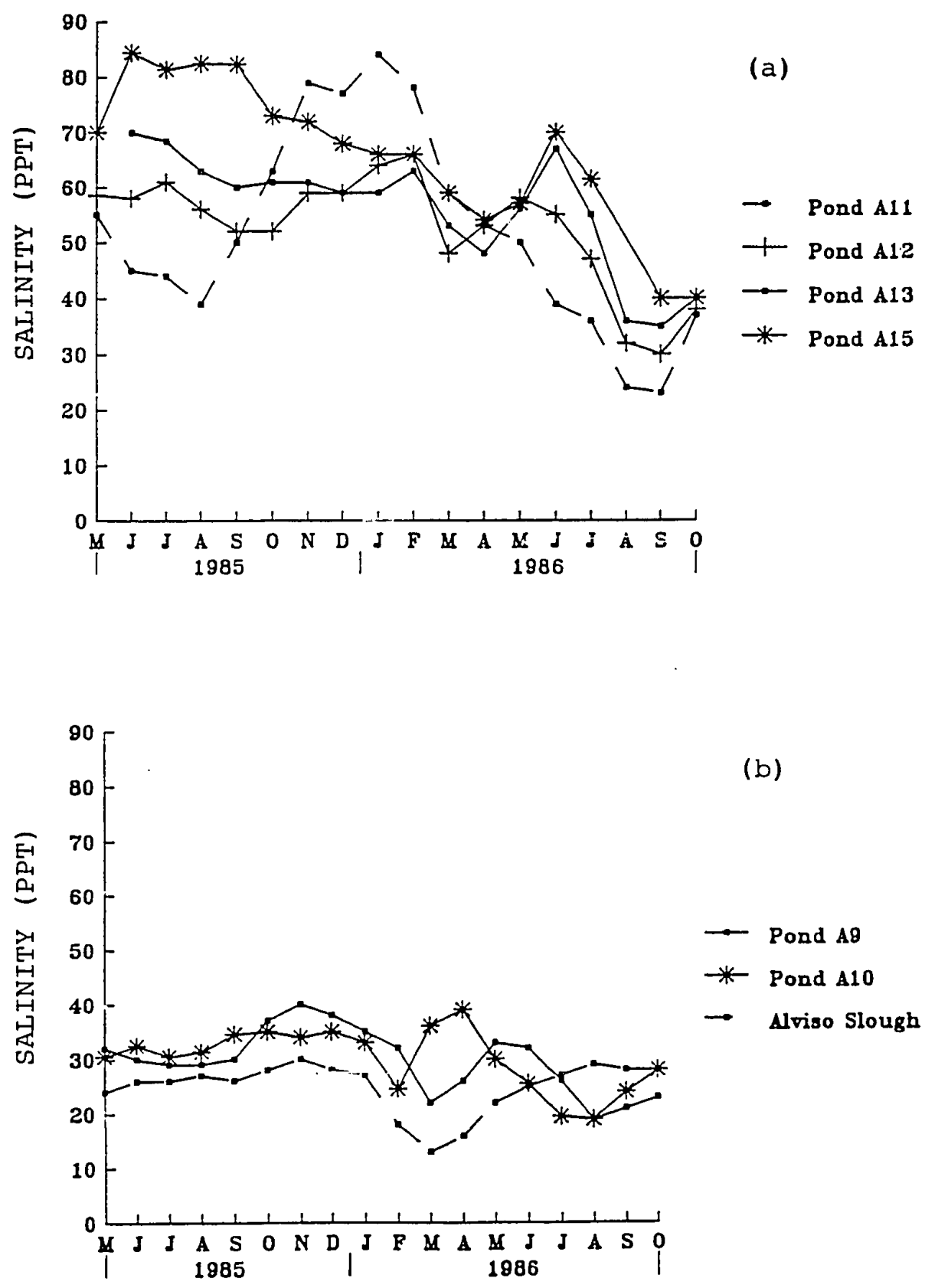

Figure 2a-b: Mean monthly surface salinities measured at NS stations in Alviso salt poilds from May 1985 to october 1986. 
salinities at southshore sites were 2 ppt greater than means at northshore sites. The greatest salinity gradient with depth was found in Pond A9 during June of 1986, following the introduction of water from Alviso Slough; surface salinity at that time was $25 \mathrm{ppt}$, while bottom salinity, at 1.5 meters, was 31 ppt. Greater salinity gradients may develop briefly following rainstorms; however, measurements could not be made during these times because wet levee roads were impassable.

Seasonal and spatial variations in pond salinities were affected by the salinity and duration of surface water inputs (i.e., from Alviso slough or preceding ponas), and temporal differences in rates of evaporation and precipitation. Surface water inputs into the ponds (i.e. from Alviso Slough and Pond A8) were seasonal and regulated by the Leslie salt Company. The diversion of water from Alviso slough into the ponds depended on pond water levels, and both pond and slough salinities. Generally, water from Alviso slough was diverted into Pond $A 9$ in the months of highest slough salinities, between June and November. The timing of water diversions from Pond $A 8$ into Pond All varied annually; diversions in 1985 were more frequent than in 1986. 
Temporal change in salinity within the two low salinity ponds is probably constant from year to year, but the range of salinities and mean concentrations may vary annually depending on rates of evaporation and precipitation. In 1986 the highest salinities in Pond $A 9$ and $A 10$ were recorded in the spring, just prior to the introduction of brackish Alviso slough water. Salinities dropped in the summer despite increased rates of evaporation, because the salinity of the in-flowing slough water (range 2b-25 ppt) during these months was lower than that of the ponds $(3 \theta-35$ ppt). By early fall, however, both evaporation and high Alviso slough salinities forced pond salinities upward once more. The two ponds differed in salinity trends in the late winter 1986. At that time salinities in Pond A9 declined, while salinities in $A l D$ increased. The decline in Pond A9 paralleled that found in the four high salinity ponds (Ponds All to Al5) and was due to a heavy rainstorm in February. Salinity increased in Pond Al0 when high salinity water was diverted into this pond from Pond All following the storm. In winter, salinities varied with the amount and timing of precipitation. Heavy winter storms, such as during February of 1986, directly reduced salinities in Ponds $A 9$ and $A 10$, and also indirectly altered pond salinities by reducing the slough salinities in the subsequent months. 
Seasonal and annual variations in source water inputs to Pond All and from Pond Al4 into Al 3 and Al5 had a profound effect on annual salinity trends in the high salinity ponds. In the summer and fall of 1985, the surface water inputs into Pond All came from both Pond $A l \theta$ and Pond A8, whereas over the same period in 1986 only water from Pond AlD was moved into Pond All. As a result of these input differences, salinities in Ponds All through Al5 were high (40-85 ppt) and relatively stable in the summer and fall of 1985, but fell sharply (25-40 ppt) during the same period in 1986. The highest salinities in Pond All were recorded in the late winter and spring of 1986 when high salinity water from Pond $A 8$ was pumped through Pond All. Salinities peaked in the other three ponds later that spring when high salinity water from Ponds All and Al4 began to circulate through the system. Heavy rains of February 1986 reduced salinities in the ponds by as much as 20 ppt, but evaporation increased salinities by as much as 20 ppt over the following two months.

\section{Depth}

With the exception of Ponds $A 9$ and $A 15$, the ponds were subject to large seasonal fluctuations in water depth (Fig. 3a-b). In Ponds Ald through Al3, where maximum relative 

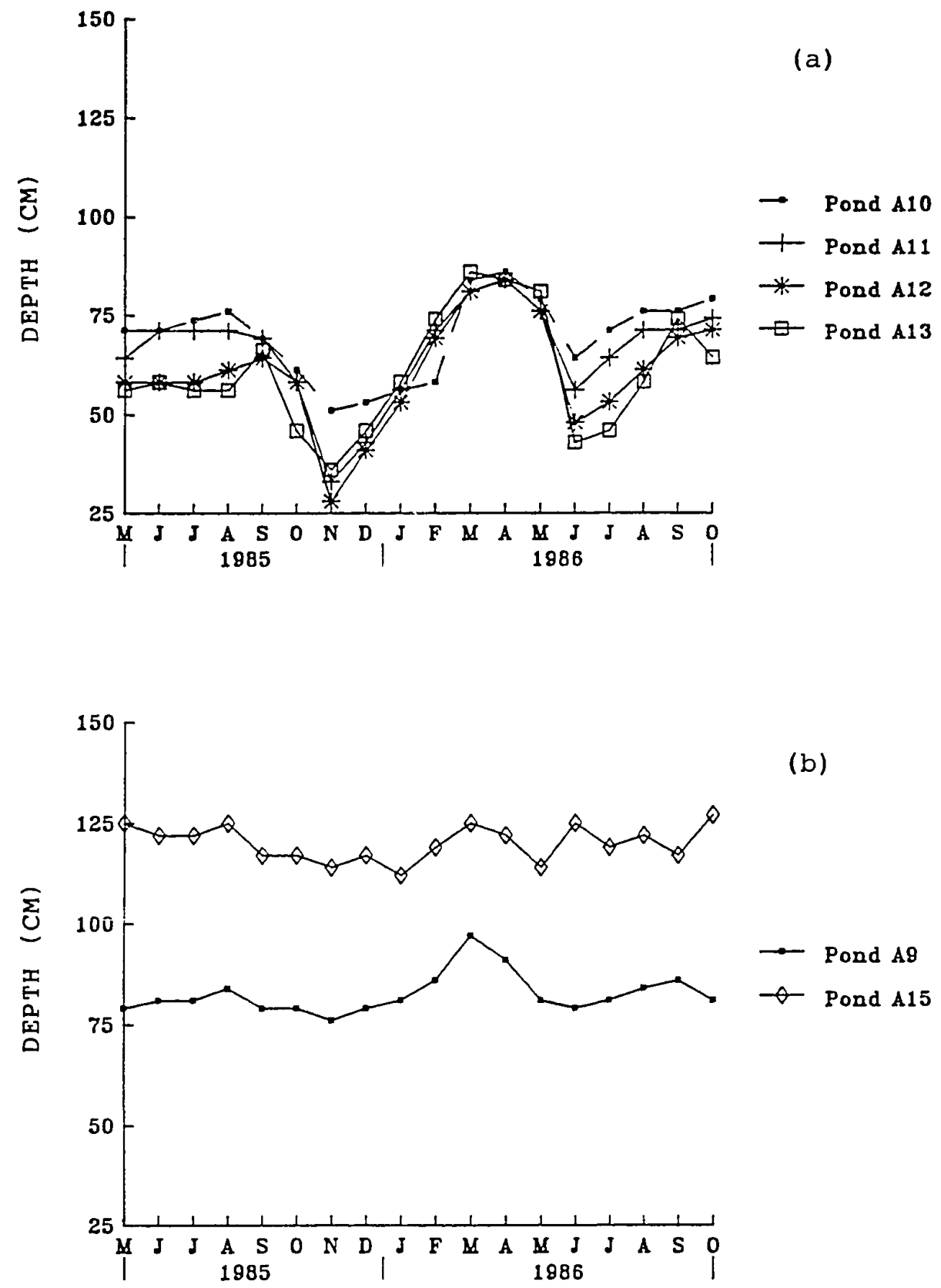

Figure 3a-b: Mean monthly depth measurements $(\mathrm{cm})$ recorded at shoreline stations in Alviso salt ponds from May 1985 to November 1986 . 
depths at shoreline sites measured less than 0.9 meters, depths varied by as much as 0.6 meters or 67 percent. These fluctuations in pond depth occurred biannually, and often took place rapidly. For example, in the fall of 1985 water depths in Ponds All-Al3 fell by as much as $40 \mathrm{~cm}$ in less than one month. Depth at shoreline sites was typical of most of the pond, with the exception of the remnant tidal slough channels and dredged (borrow) pits bordering the pond perimeter. During periods when water levels were lowest, the only areas deeper than 0.6 meters were the borrow pits and slough channels.

Seasonal fluctuations in pond depth were affected by races of evaporation and precipitation, and the timing and magnitude of regulated water diversions. In Ponds Alס-Al3, water diversions at Pond Al3 were the major cause of seasonal change. As water was diverted from this pond, the lowered water level of Al3 resulted in gravity flow from pond A9 through Al2 to refill Al3. When this water was pumped in the late fall or late spring, there was no incoming flow from Alviso slough to compensate for these diversions, and consequently water levels in Ponds A10-A13 dropped dramatically (i.e. fall of 1985 and spring of 1986). Water depths in Ponds A9-Al3 increased during the summer and fall, when inflows from Ponds $A 10$ and $A 8$ were greater than 
outflows. Seasonal changes in rates of precipitation and evaporation played an unpredictable, but important role in regulating pond depths. A heavy storm in February 1986 increased pond depths by $10 \mathrm{~cm}$ in a single week. Evaporation reduced depths by as much as $8 \mathrm{~cm}$ per month.

\section{Water temperature}

Mean monthly morning northshore surface water temperatures ranged from 6 to 25 degrees $c$ over the one and one-half year study, and were very similar among all six salt ponds (Fig. 4). Mean monthly water temperature at northshore sites ranged 6-10 degrees C (Fig. 5). The highest temperature recorded in the ponds was 28 degrees $\mathrm{C}$ in July 1986, and the lowest was 5 degrees $C$ in December 1985 (Fig. 5).

Surface water temperatures measured in the morning at northshore sites closely paralleled air temperatures during most months of the study (Fig. 6). Diurnal patterns of aiz and water temperature variation were also similar. Diurnal fluctuations in pond temperatures were most extreme in the spring of 1986 (Table 1), when pond A9 temperatures varied by $6 \mathrm{C}$ over 18 hours on 16 May 1986. Diurnal temperature changes were 4 degrees C or less in November 1985, July 1985, and February 1986. Thermal stratification was 


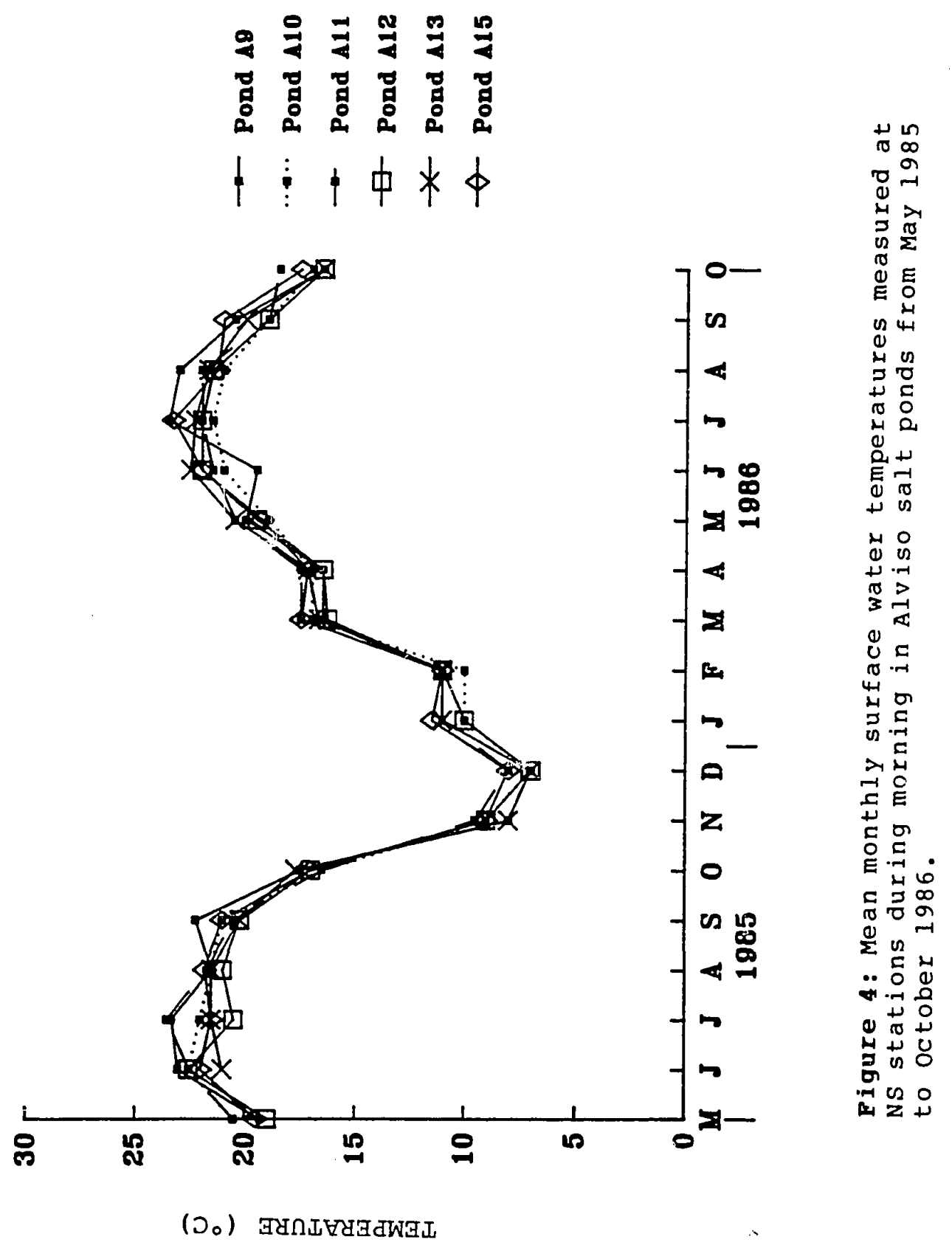




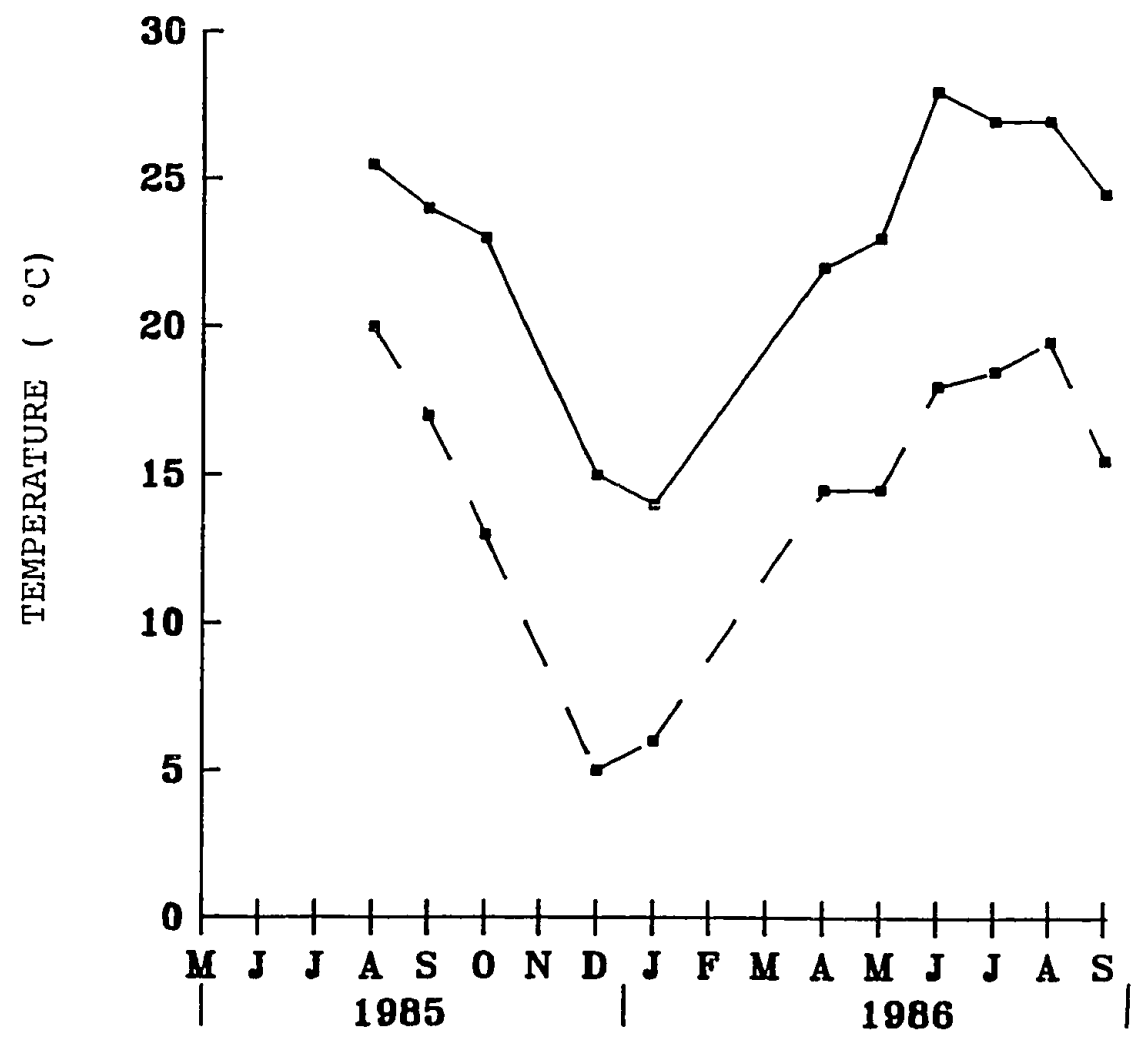

Pigure 5: Mean monthly maximum (solid line) and minimum (dashed line) surface water temperatures measured in Alviso salt ponds from August 1985 to september 1986. 


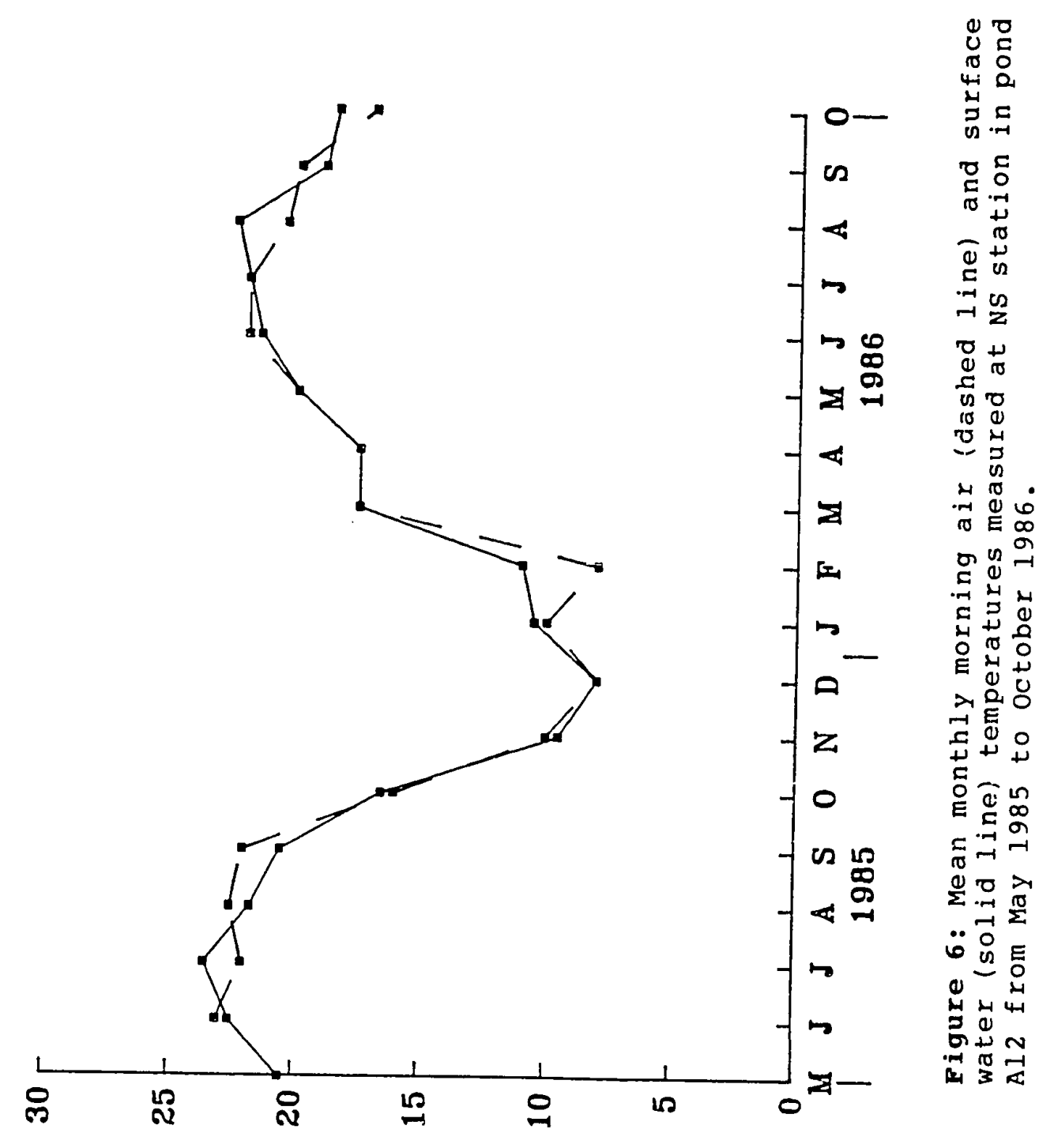

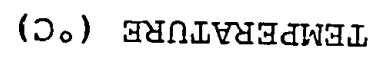



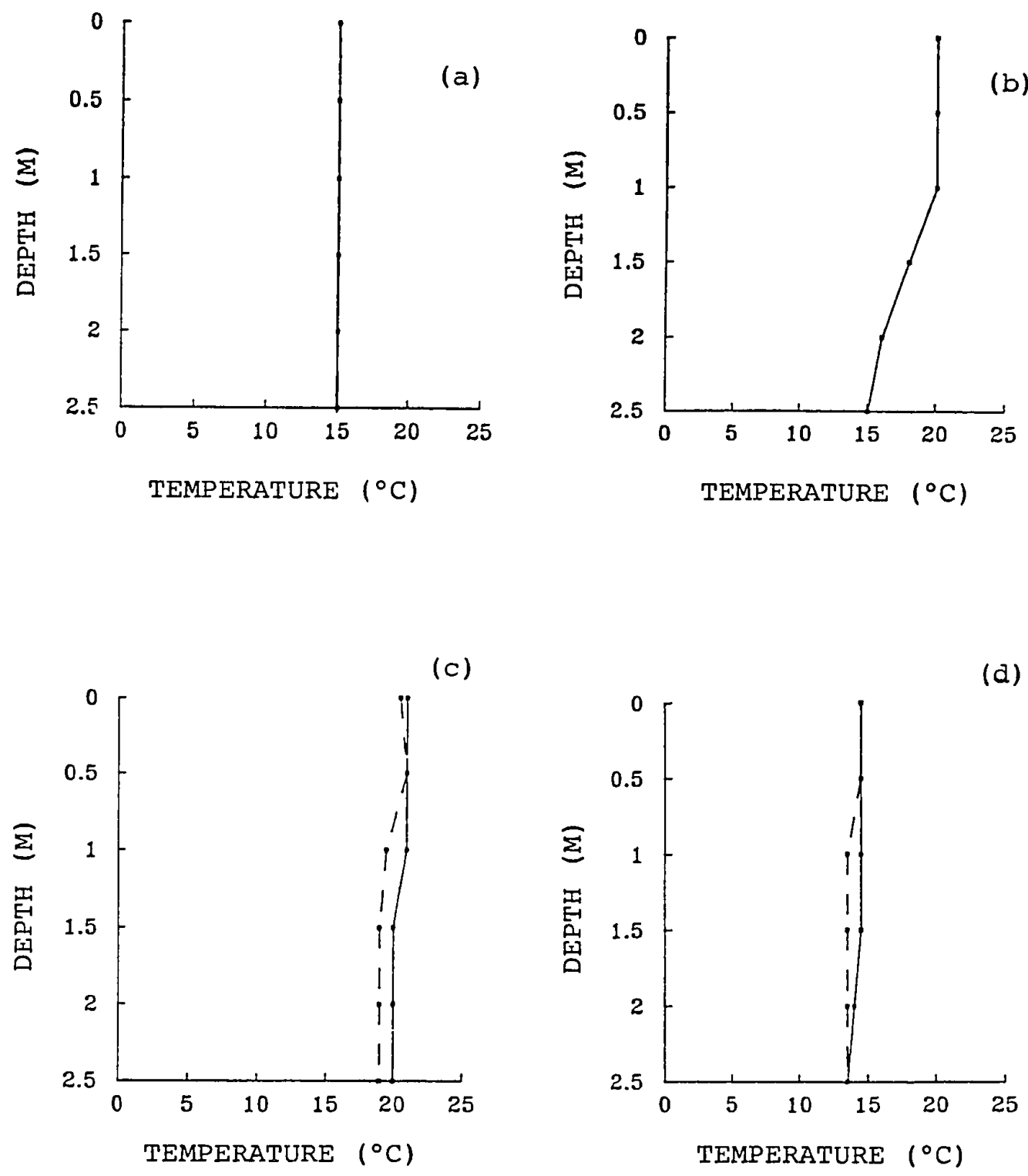

Figure 7a-d: Morning (dashed 1 ine) and afternoon (solid line) temperature profiles from Pond Al 3 for seasonal sampling dates (a) $22 \mathrm{Jan} \mathrm{1986;} \mathrm{(b)} 22 \mathrm{Mar} 1986$; (c) $28 \mathrm{Jun} 1986$; (d) $22 \mathrm{Nov}$ 1986. 

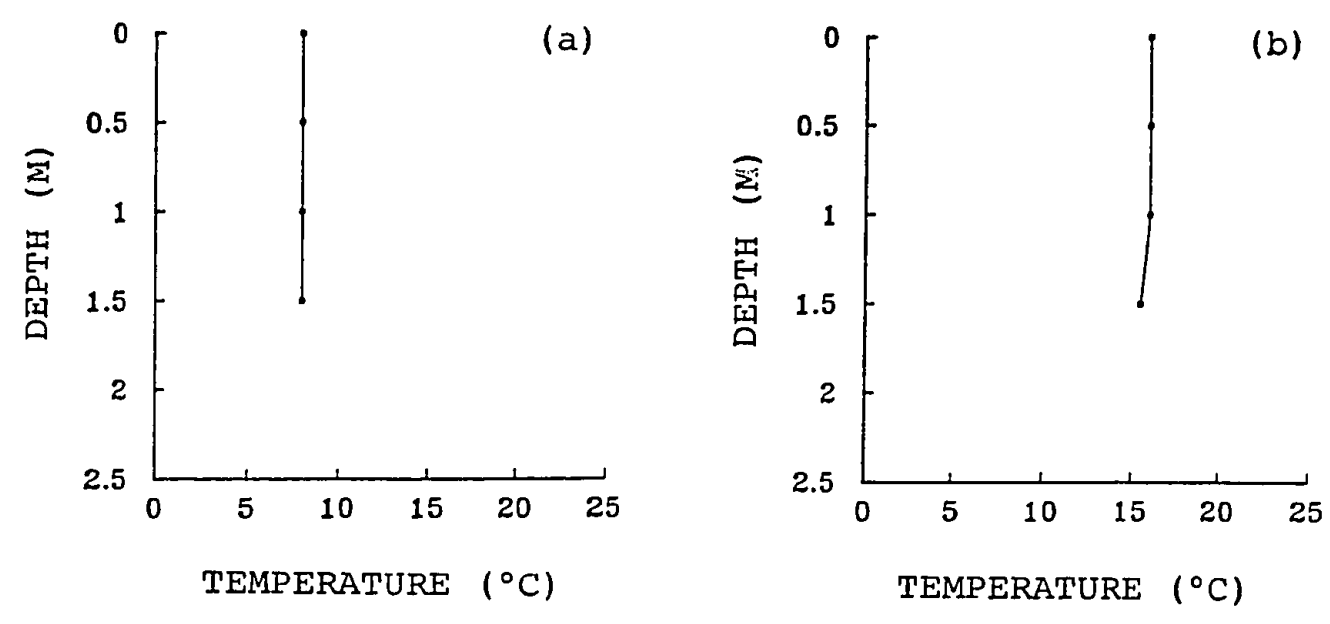

(c)
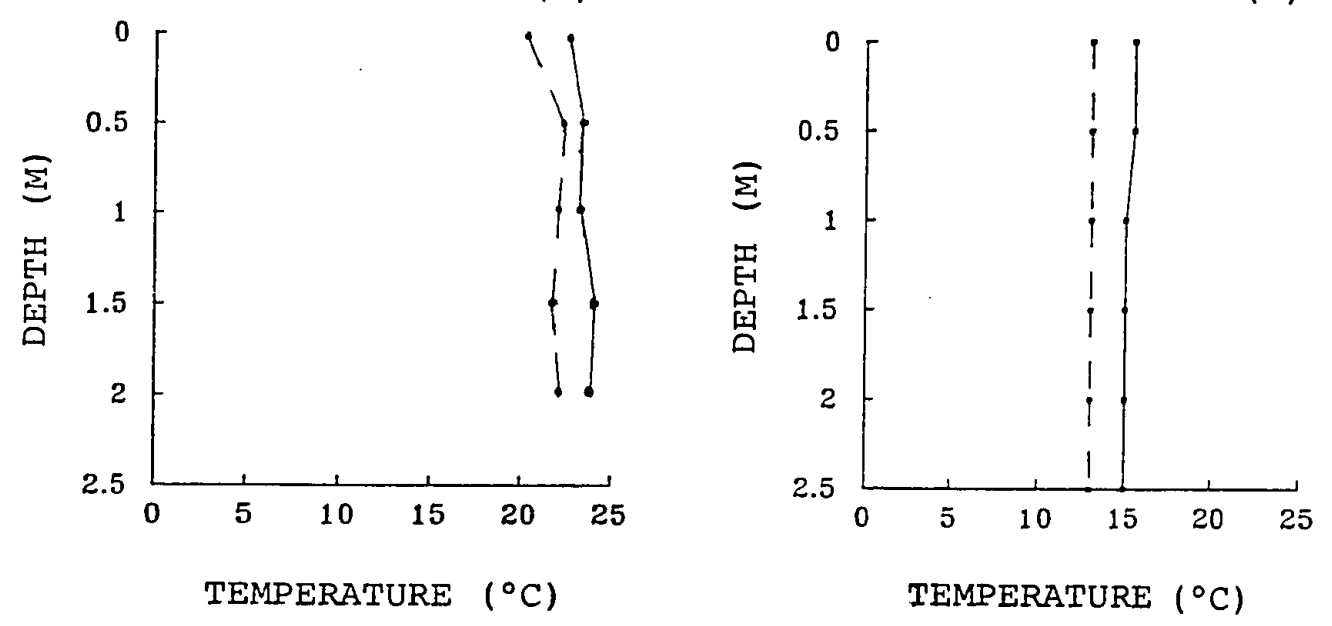

Figure 8a-d: Morning (dashed line) and afternoon (solid line) temperature profiles from Pond A9 for seasonal sampling dates (a) $22 \mathrm{Jan} 1986 ;$ (b) $22 \mathrm{Mar} 1986$; (c) $28 \mathrm{Jun} 1986$; (d) 22 Nov 1986. 


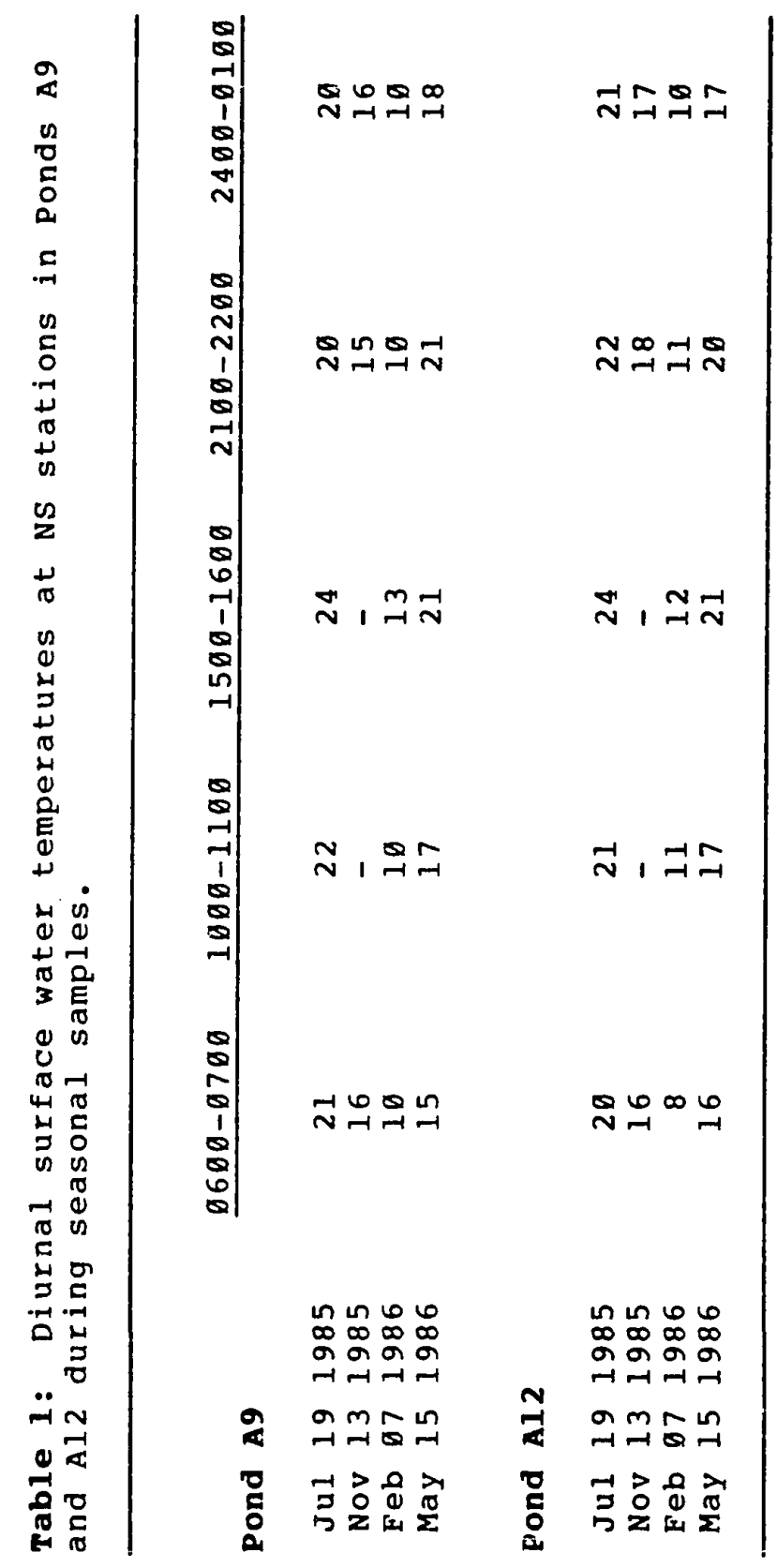


seasonally variable. In March 1986, temperature differences between the surface and bottom were as great as 6 degrees $c$, but in other seasons, and in shallower ponds, temperature differences were no greater than 2 degrees C (Fig. 7a-d, 8ad).

pH

The $\mathrm{pH}$ in the salt ponds varied seasonally and with pond type. Morning $\mathrm{pH}$ in the six ponds showed a negative correlation with pond salinity $(r=-0.53, p<0.05)$ (Fig. 9). The highest pHs were recorded in the two low salinity ponds, with values typically 0.5 points greater than in the high salinity ponds (Fig. Iø a-b). Minimum individual pH was similar in all ponds, at $7.7-8.0$, but the maximum values varied with salinity. In the low salinity ponds, the highest $\mathrm{pH}$ was 9.3-9.5, whereas in Ponds Al2, Al3, and Al5 the maximum level was only 8.7. Pond All was subject to sharp salinity changes, and $\mathrm{pH}$ reached 9.9-9.2 when salinities fell to 30 ppt.

Fluctuations in $\mathrm{pH}$ were often very dramatic, especially in the low salinity ponds (Fig. loa). The pH significantly increased to 9.5 in Pond $A 9$ in the May 1986, during a period of maximum macroalgal cover. A general decline in $\mathrm{pH}$ occurred in the summer with the introduction of low $\mathrm{pH}$ ( $\mathrm{pH}=$ 


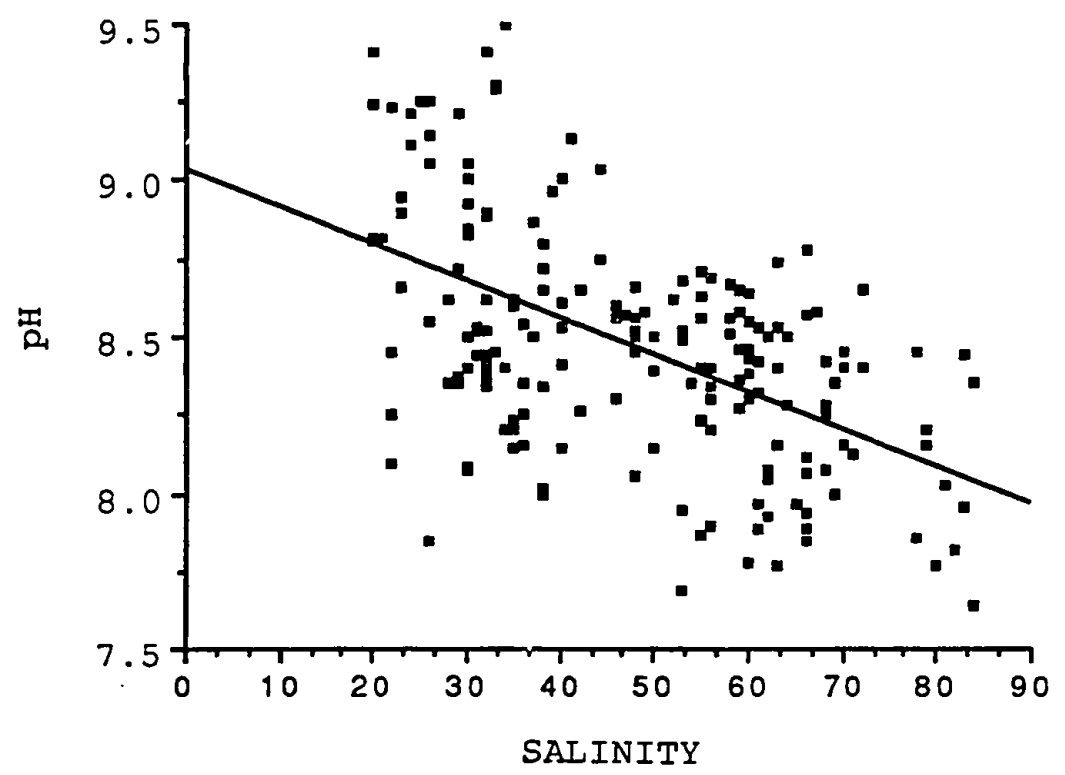

Figure 9: Morning NS station pH plotted against salinity from Alviso salt ponds from April 1985 to November 1986 ( $r=-0.53)$. 

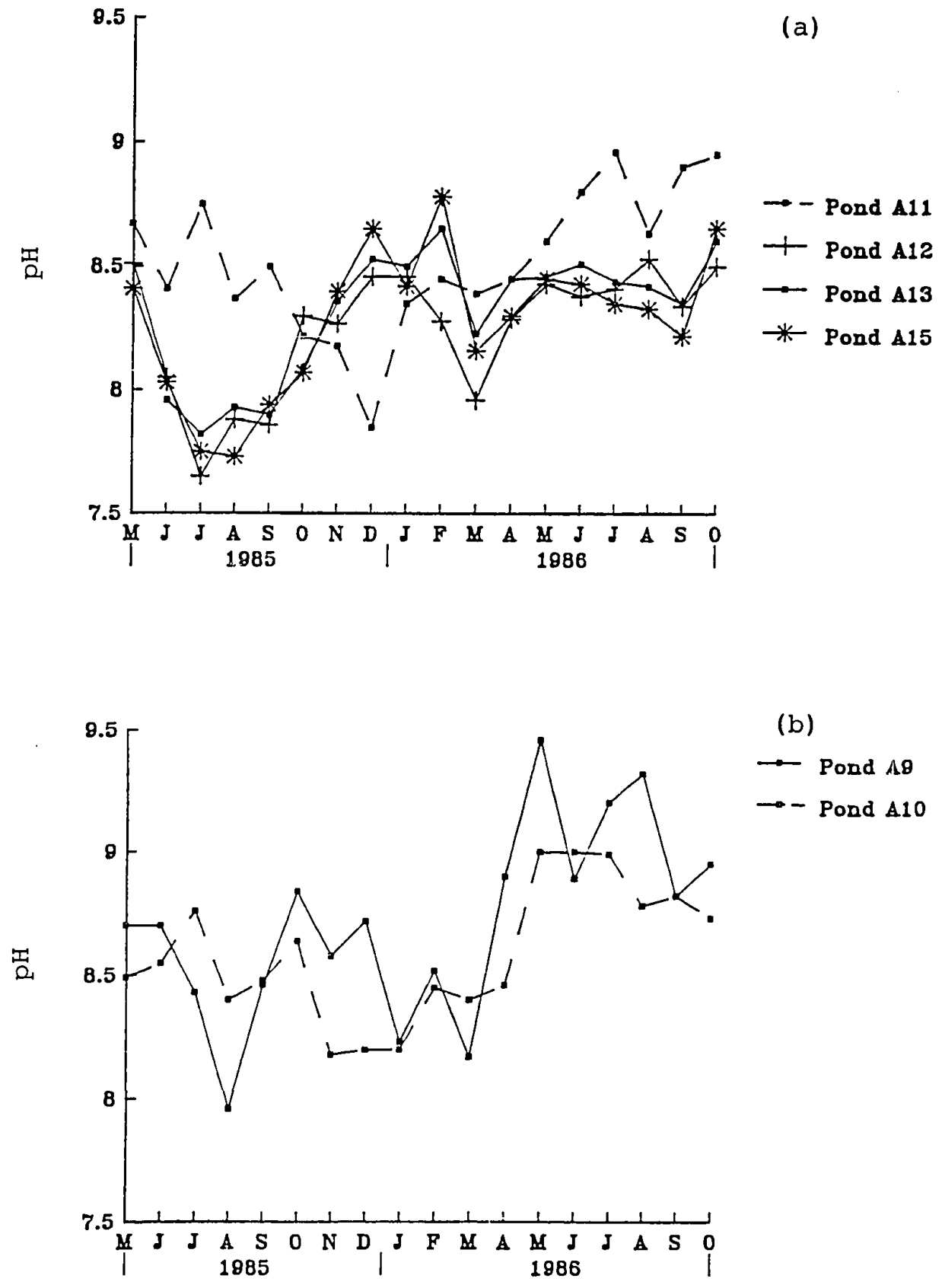

Figure 16a-b: Mean monthly morning pH measured at NS stations in Alviso salt ponds from May 1985 to october $19 \overline{8} 6$. 
8.0 - 8.4) water from Alviso slough. In the high salinity ponds pH also fluctuated widely, with the highest pH during the summer of 1986, the period of lowest salinity (Fig. 10 b).

Multiple regression analyses demonstrated that pond pH's were correlated with salinity, temperature, and dissolved oxygen, although these correlations were not consistent from pond to pond. In the high salinity ponds $\mathrm{pH}$ was inversely correlated with salinity and positively correlated with both temperature and dissolved oxygen. In the low salinity ponds pH did not correlate with salinity, temperature, or dissolved oxygen, but was probably most affected by photosynthetic activity. During periods of maximum algal abundance (spring 1986), $\mathrm{pH}$ increased.

\section{Secchi depth/primary production}

The results from monthly secchi depth measurements, used here as an inverse index of phytoplankton abundance, are presented in Fig. 1la-b. These results show higher relative abundance of phytoplankton in the high salinity salt ponds and wide seasonal variability in phytoplankton abundance in the low salinity ponds.

Phytoplankton was the chief source of primary productivity in the high salinity ponds (Ponds All to Al5), 

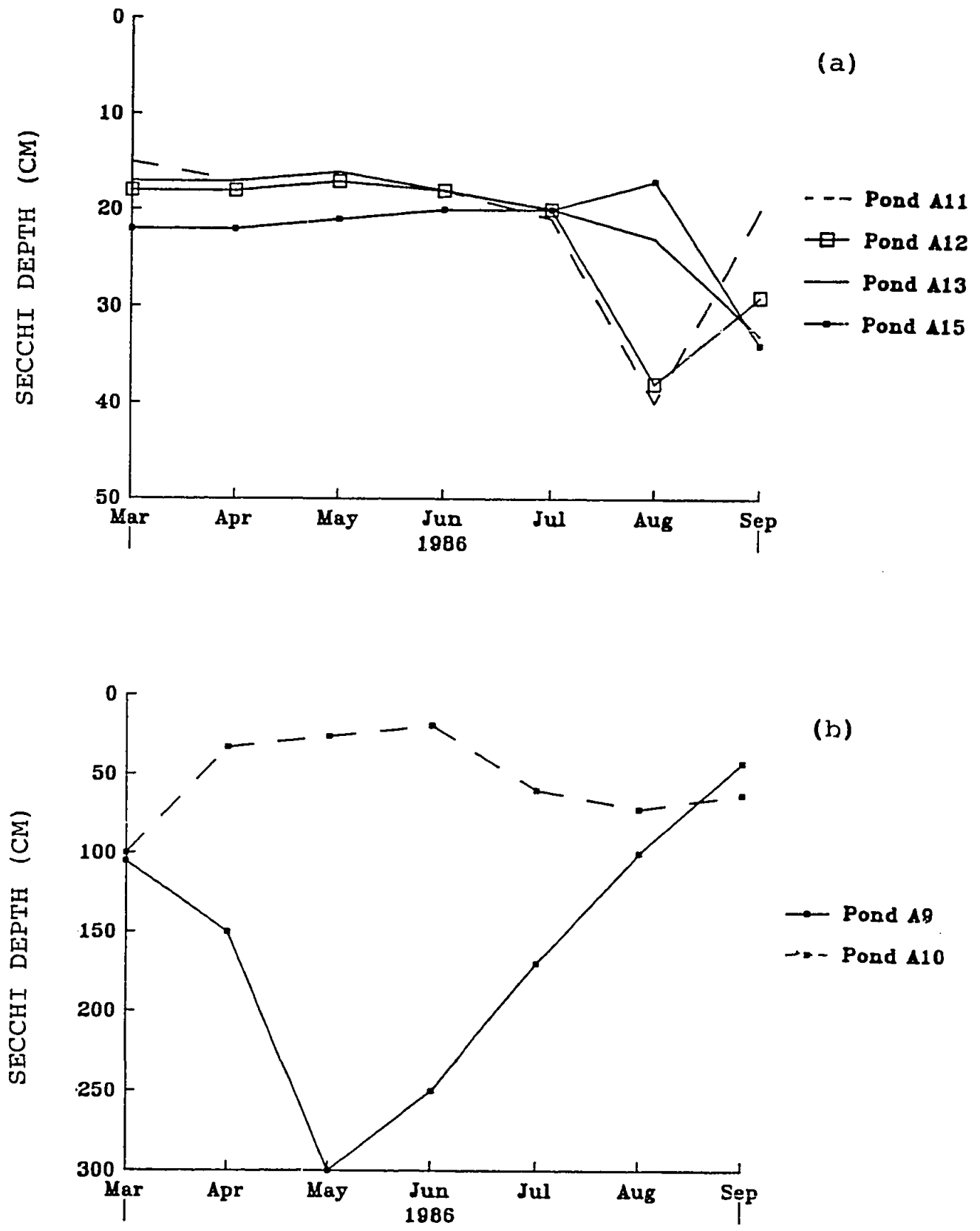

Figure Ila-b: Secchi depth for Alviso salt ponds from March to september 1986. Note scale change. 
and were the only plants present when salinities exceeded 40 ppt. Although salinities were low enough during several months for macroalgae (i.e. Enteromorpha sp. and Ulva sp.) to grow, they never became a significant component of the algal community of Ponds All to Al5. From March through July 1986, secchi depth measurements among the high salinity ponds were very similar, ranging from 15 to $22 \mathrm{~cm}$ (Fig. 11b). However, secchi depths increased sharply in Pond All and Al2 in August, and in Ponds Al3 and Al5 in september following salinity declines produced by regulated water movements among ponds. Secchi deptins in each of the four high salinity ponds (Ponds All to Al5) were inversely correlated with salinity, indicating increasing phytoplankton abundance at high salinities (Fig. 12a-f and Fig. 13)

The low salinities of Ponds A9 and AlD were suitable for both phytoplankton and macroalgae, and both were present. Dominance by one group or the other depended on the season and pond water quality. Phytoplankton abundance in Pond A9 decreased from March to May 1986, then progressively increased until the conclusion of the study (Fig. lla). Unlike the high salinity ponds, secchi depth in Pond $\bar{A} 9$ was negatively correlated with salinity $(r=-0.91)$ (Fig. 12e). Pond AlO showed increased phytoplankton abundance from March through June 1986 and declines 

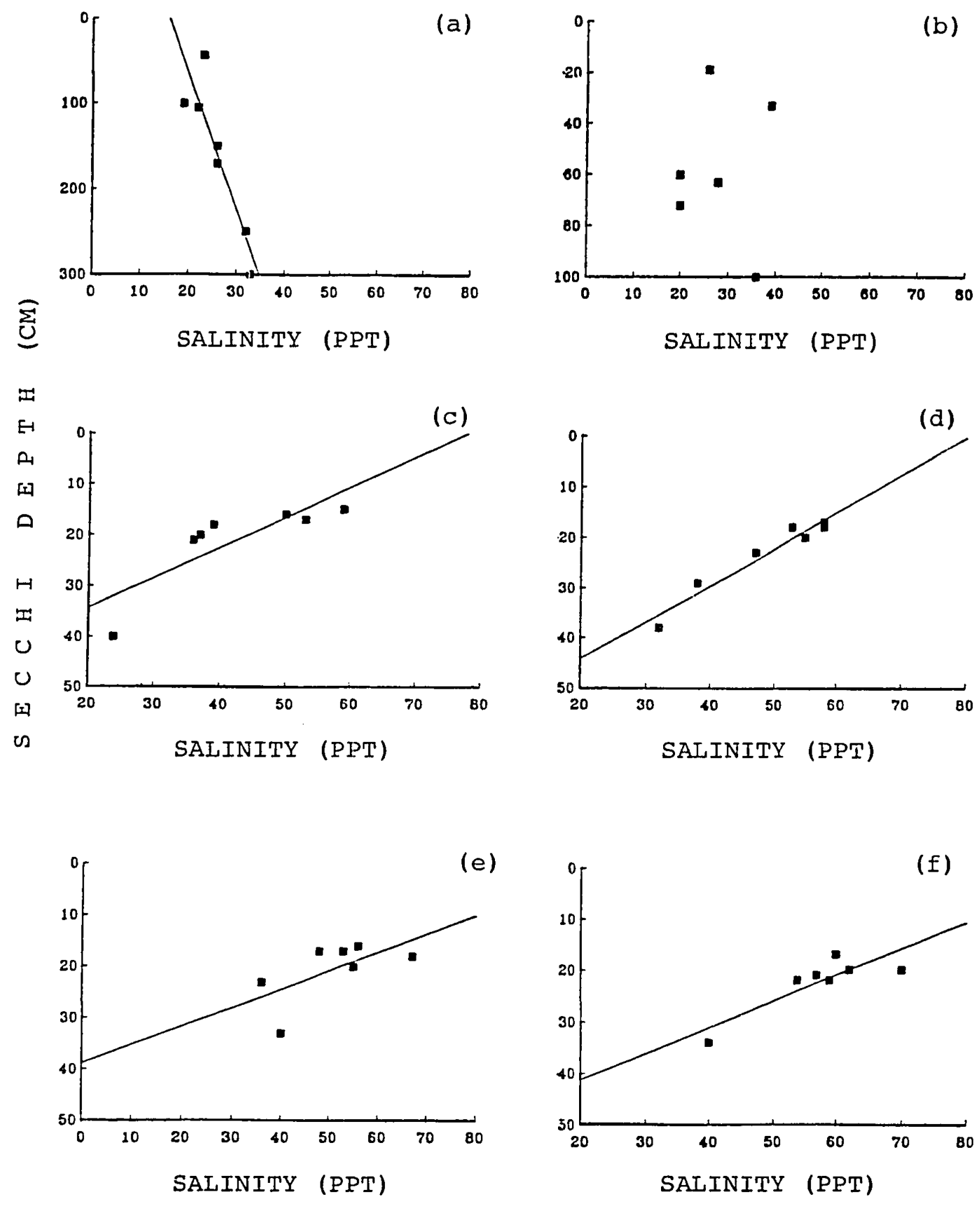

Figure 12a-f: Monthly secchi depths plotted versus salinity in Alviso salt ponds. (a) Pond $A 9$; (b) Pond $A l \emptyset$; (c) Pond All; (d) Pond Al2; (e) Pond Al3; (f) Pond Al5. 


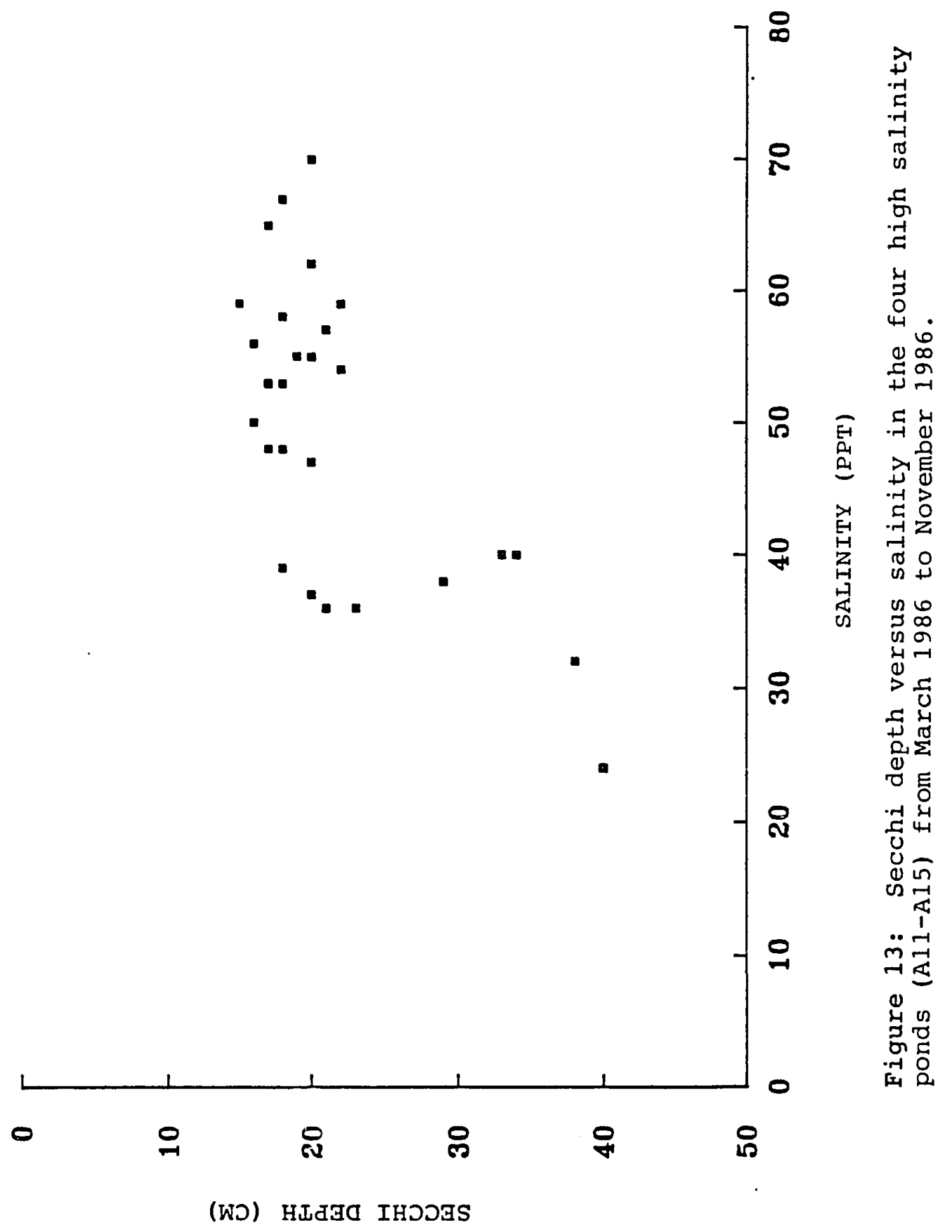


thereafter; there was no correlation between salinity and phytoplankton.

Secchi depths in the two low salinity ponds, pond A9 and $A 10$, were usually much greater than in the high salinity ponds (Fig. 11a). Those differences and the seasonal changes in secchi depth and phytoplankton abundance may reflect competition between phytoplankton and macroalgae for light and nutrients. In the summer and fall of 1985 , macroalgae, predominantly Enteromorpha, occupied as much as 60 percent of the surface of Pond A9 (Table 2). Macroalgae decreased to 25-30 percent cover in winter and early spring 1986, then increased again to 60 percent cover in Juñe of 1986. This increase in surface macroalgal cover in 1986 was paralleled by a large increase in secchi depth, reflecting a sharp reduction in phytoplankton abundance (Fig. 1la). Macroalgal cover decreased from June to september 1986 (Table 2), and was accompanied by increased phytoplankton abundance and decreased secchi depths (Fig. 1la). Enteromorpha was not as abundant in Pond $A l \emptyset$ as in Pond A9 (Table 2). It was most common in pond Ald during the fall and early winter of 1985-86, but died back in the winter and early spring of 1986, when the movement of water from Pond All back into Pond $A 10$ drove salinities above 35 ppt. Phytoplankton then became the dominant plants through 
Table 2: Estimated percent surface cover for Enteromorpha in Fonds $A 9$ and $A 10$, for August 1985 to september 1986 .

\begin{tabular}{llcc}
\hline Date & & Pond A9 & Pond Al 0 \\
\hline August & 1985 & $5 \emptyset$ & 25 \\
October & 1985 & 60 & 15 \\
& & & \\
January & 1986 & 25 & 15 \\
April & 1986 & $3 \emptyset$ & $<1 \emptyset$ \\
June & 1986 & 60 & $<1$ \\
July & 1986 & 25 & $<1$ \\
September & 1986 & 20 & 5 \\
\hline
\end{tabular}


the summer and fall, although their abundance declined in the late summer (Fig. 11a). Enteromorpha growth increased in september in the shallow waters of the pond (Table 2).

\section{Dissolvea oxygen}

Mean northshore dissolved oxygen levels for the six ponds reflected the effect of temperature and salinity on maximum oxygen saturation. Levels were negatively correlated with salinity $(r=-0.7, p<0.05)$ in all six ponds, and with temperature in the four high salinity ponds $(\mathrm{r}=-0.6, \mathrm{p}<0.05)$. However, seasonal and daily variations in dissolved oxygen within ponds were large (Fig. 14a-d, Table 3) and reflected the additional effects of photosynthesis, wind action, and decomposition. Highest surface dissolved oxygen values in the high salinity ponds were during the winter months (Fig. $14 \mathrm{~b}-\mathrm{d}$ ) and were probably caused by low pond water temperatures. Lowest leveis were present in June and July 1985, with a range of 3.1 to 4.0 $\mathrm{mg} / \mathrm{l}$ in the four ponds. In Pond All, these low values were due to decaying vegetation transported by the inflows from Pond Al6. These low values continued through the early fall of that year in pond $A l l$ and then occurred again in summer of 1986 (range $4.1-5.3 \mathrm{mg} / 1$ ). In Ponds Al2, Al3, and Al5, the dissolved oxygen decline in summer of 1985 was probably 

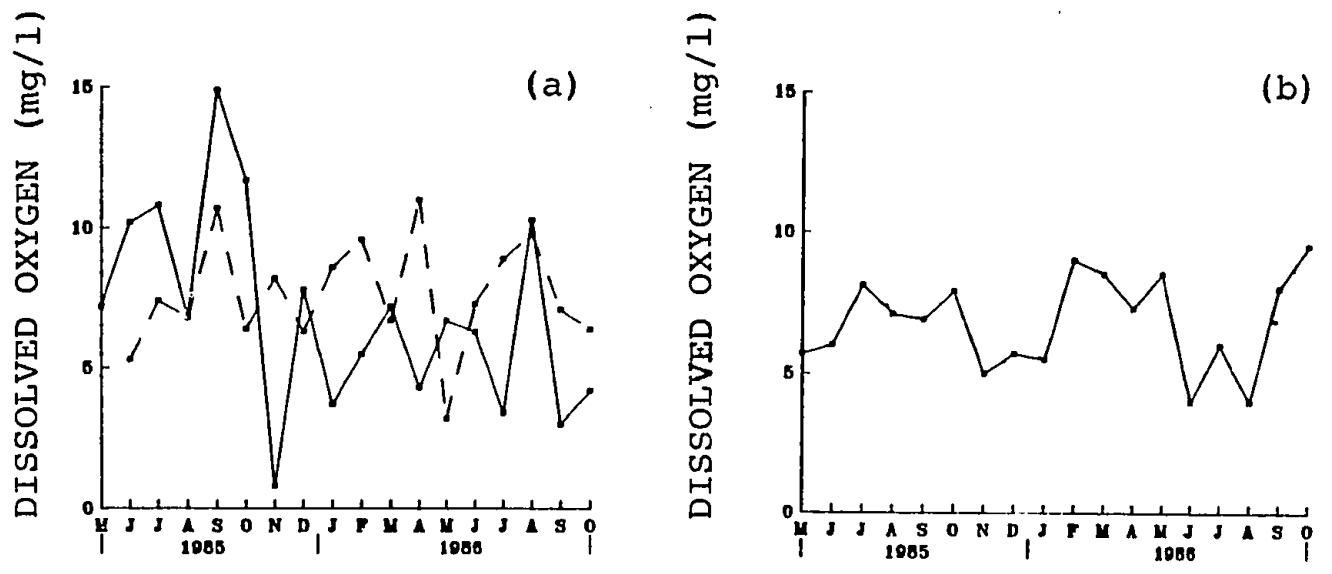

POND A9 NS -

POND A9 SS ---

POND AIO -
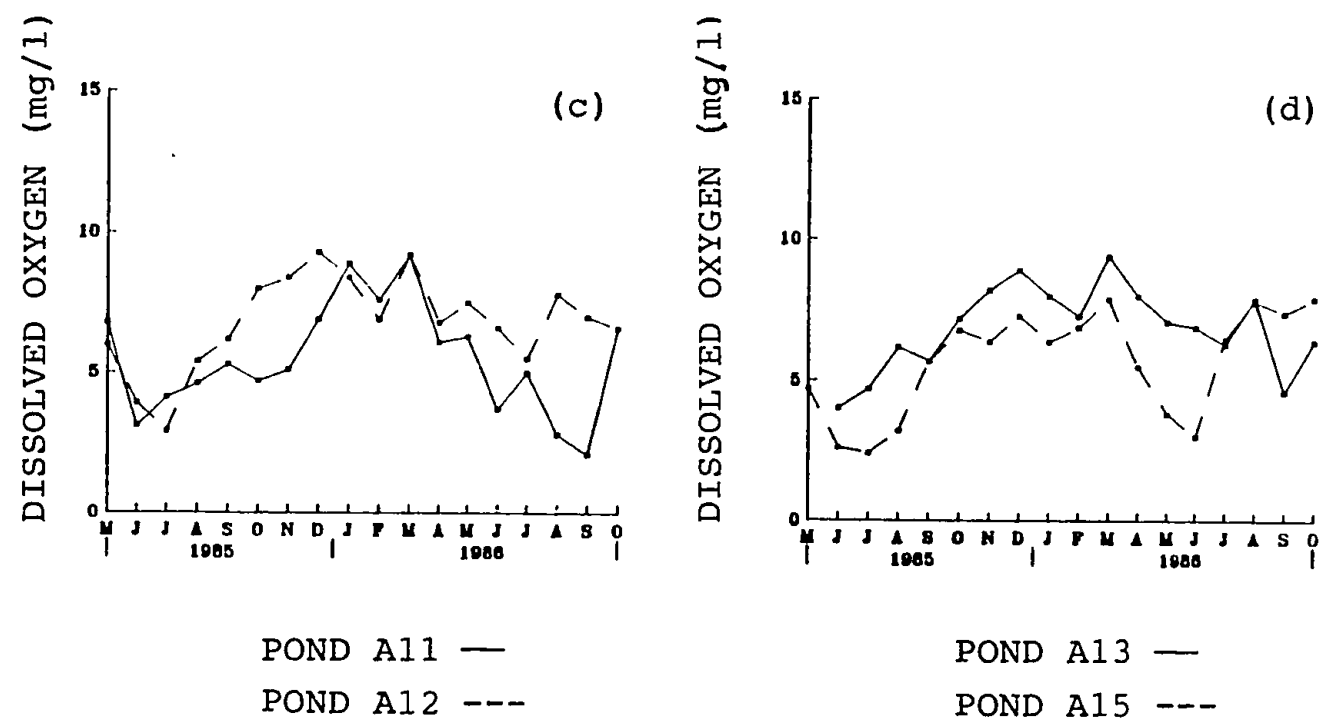

Figure 14a-d: Mean monthly dissolved oxygen levels measured at NS stations during morning hours in six salt ponds from May 1985 to october 1986. (a) Pond A9 (ns/ss); (b) Pond Alo; (c) Ponds All/A12; (d) Ponds A13/Al5. 


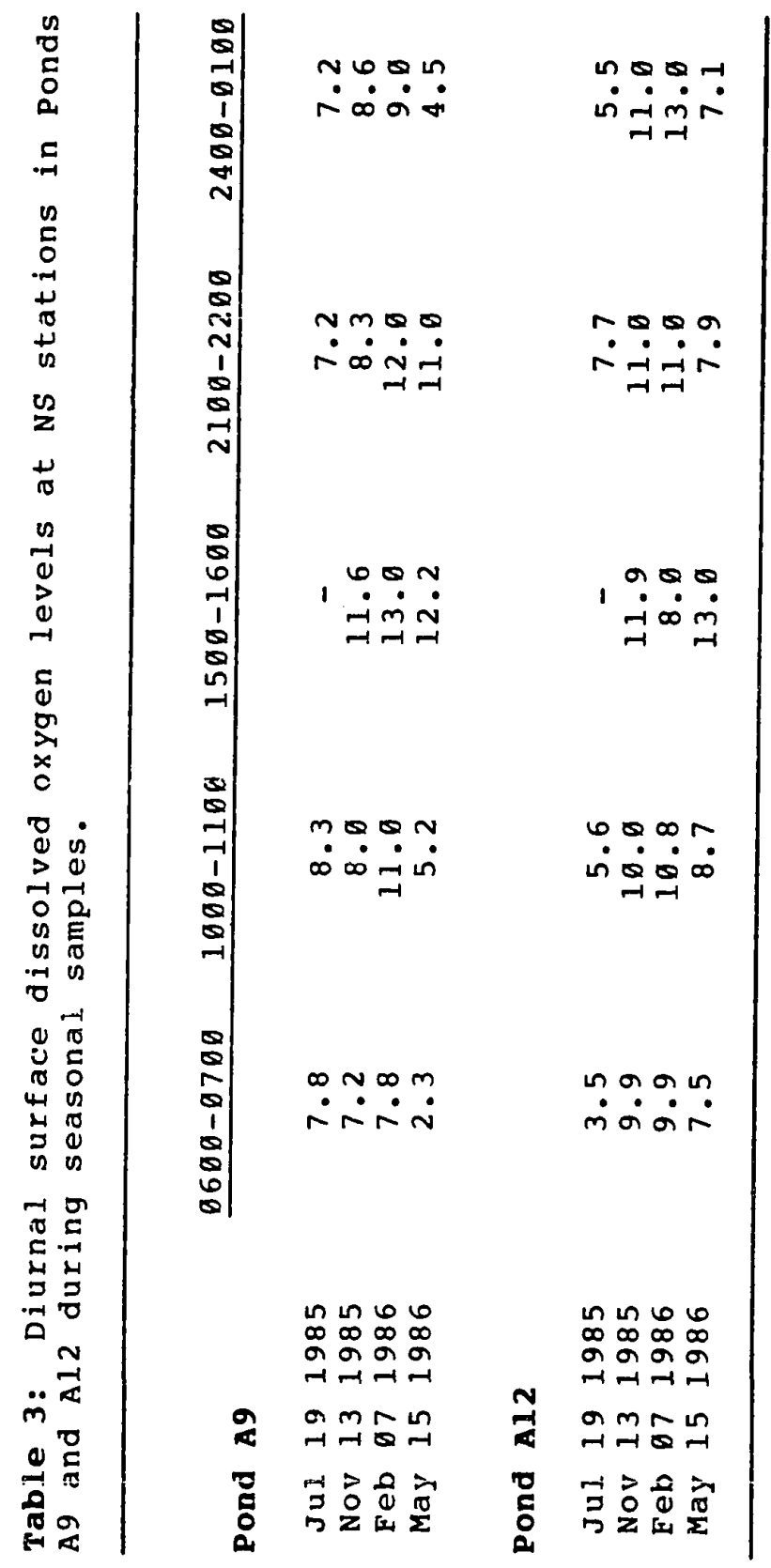


due to very high salinities. In summer 1986, when salinities in Ponds Al2 and Al3 were much lower, no dissolved oxygen decline occurred; however, in Pond Al5 salinity reached 70 ppt and dissolved oxygen dropped to as low as $3.0 \mathrm{mg} / 1$.

In the low salinity ponds there were no significant correlations of dissolved oxygen with either salinity or temperature. However, decomposition and primary production did affect dissolved oxygen. In Pond A9, morning dissolved oxygen levels at the southshore site were generally high (range $7.0-14.9 \mathrm{mg} / 1$ ) except for May of 1986 , when a local die-back of macroalgae near the southshore sharply reduced dissolved oxygen levels to $3.3 \mathrm{mg} / \mathrm{l}$ (Fig. 14a). At the northshore site dissolved oxygen levels sharply dropped in November 1985 to less than $1 \mathrm{mg} / \mathrm{l}$ following the die-back of macroalgae near that shore (Fig. 14a).

Water column dissolved oxygen stratification differed seasonally and among ponds, but bottom waters in all ponds were usually hypoxic $(<2 \mathrm{mg} / 1)$ or anoxic (Fig. 15-16). In March 1986, afternoon dissolved oxygen concentrations in high salinity ponds were supersaturated ( $8 \mathrm{mg} / 1$ ) in the upper one meter, but hypoxic $(<2 \mathrm{mg} / 1)$ towards the bottom (Fig. 15b). In June 1986, oxygen stratification in the high salinity ponds became more extreme, and oxygen was saturated 

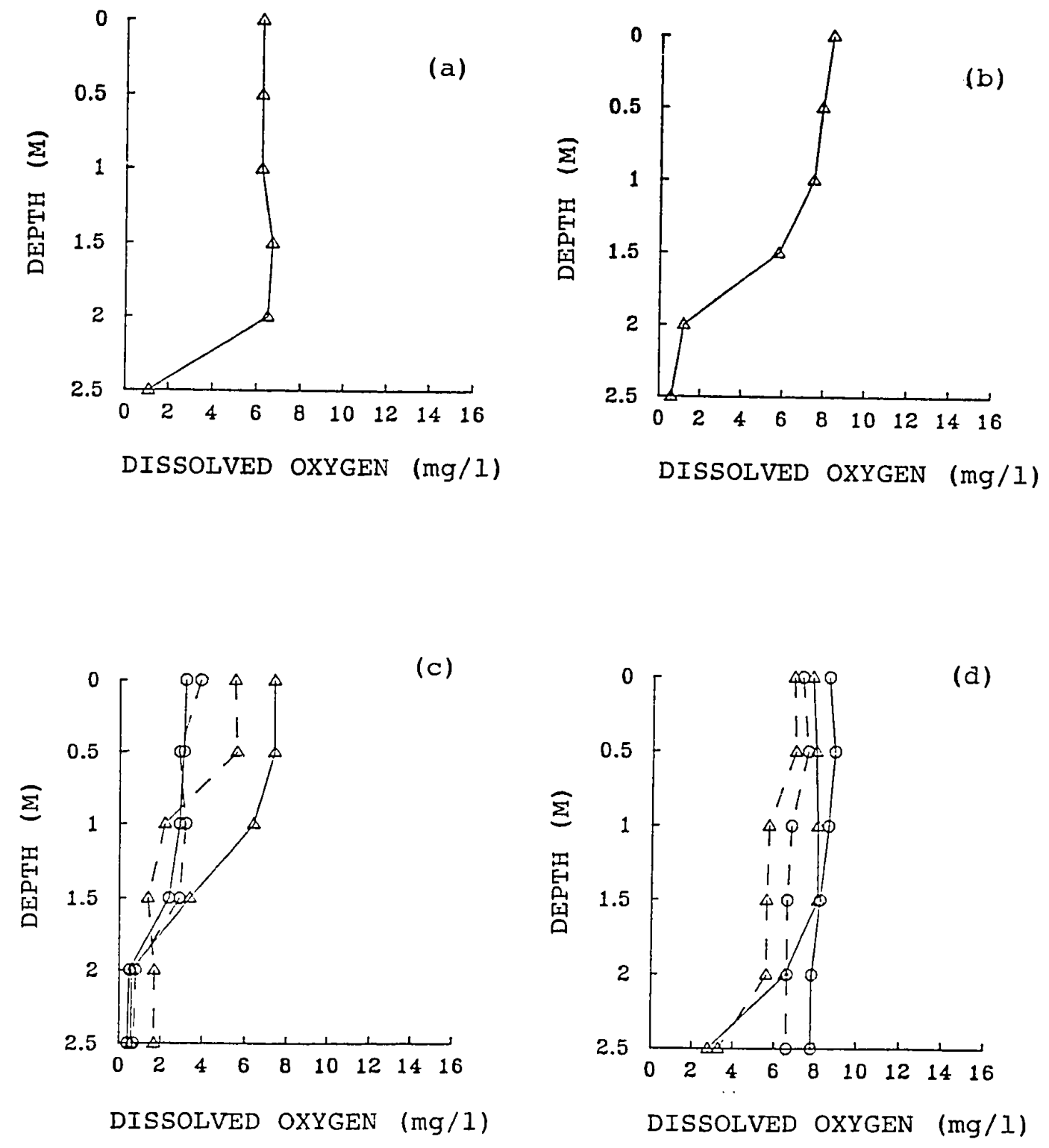

Figure 15a-d: Morning (dashed line) and afternoon (șolid line) dissolved oxygen profiles from Pond Al 3 for seasonal sampling dates. (a) $22 \mathrm{Jan} 1986$; (b) $22 \mathrm{Mar} 1986$; (c) $28 \mathrm{Jun} 1986$; (d) 22 Nov 1986. NS stations (o) and ss stations $(\Delta)$. 

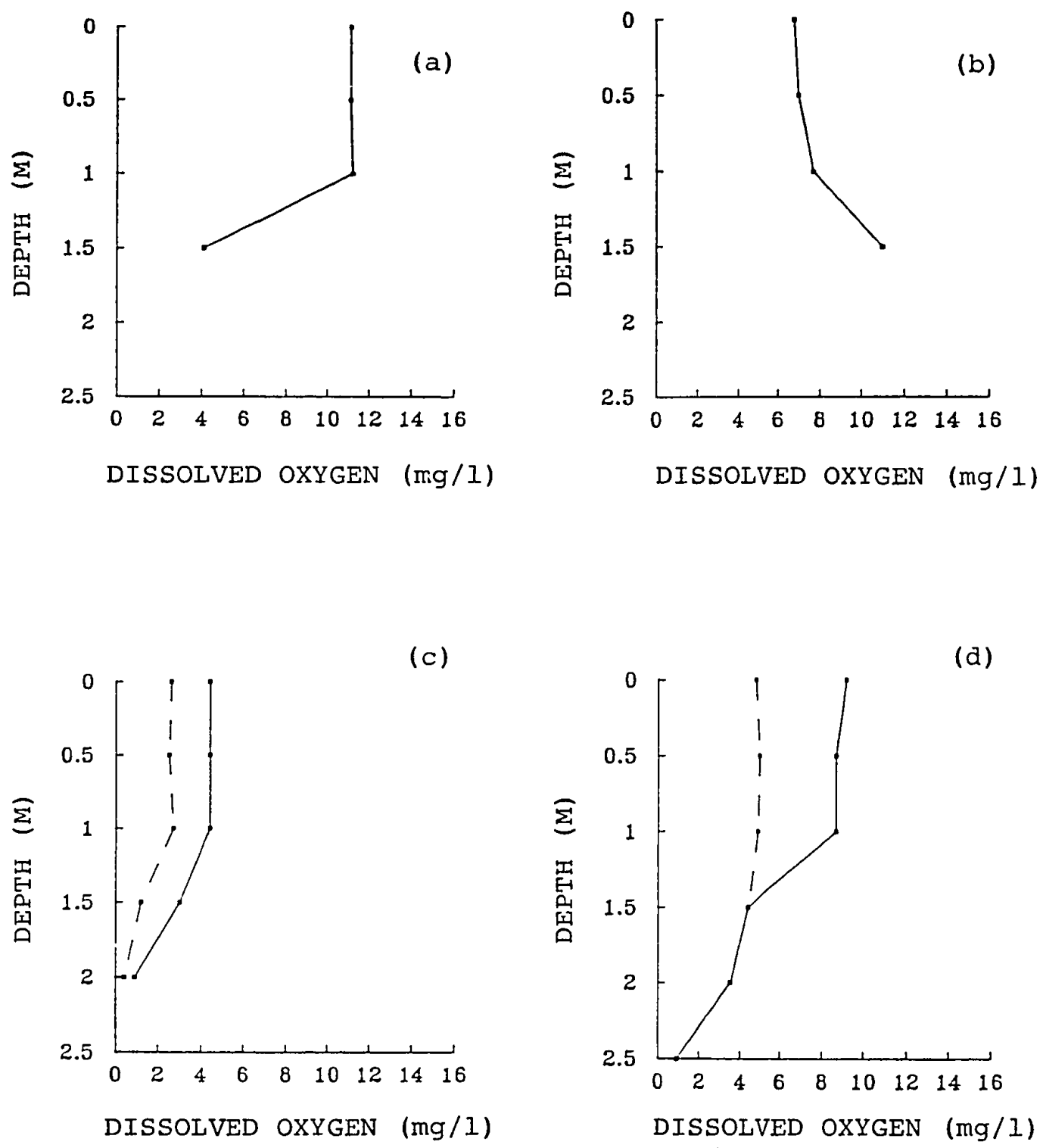

Figure 16a-d: Morning (dashed $l$ ine) and afternoon (solid line) dissolved oxygen profiles from pond A9 for seasonal sampling dates. (a) $22 \mathrm{Jan} 1986$; (b) $22 \mathrm{Mar} 1986$; (c) $28 \mathrm{Jun} 1986$; (d) 22 Nov 1986. 
or supersaturated only in the upper $1 / 2$ meter (Fig. 15c). Differences between north and south shores measured then were very pronounced. Lower values were recorded along the northshore, where the levees provided protection from northwesterly winds. Surface dissolved oxygen concentrations during summer measurements in Pond Al3 were 30 percent lower in morning at the northshore site than at the southshore site $(4.0$ vs $5.5 \mathrm{mg} / \mathrm{l})$ and 55 percent lower in the afternoon $(3.2$ vs $7.4 \mathrm{mg} / 1)$. Dissolved oxygen profiles in the November and January were similar to those observed in March (Fig. 15 a, d).

Dissolved oxygen profiles in Pond A9 were much different from the patterns measured in the high salinity ponds, primarily because of extreme seasonal variability in productivity and decomposition of macroalgae. In Pond A9, high primary productivity in March, resulted in high dissolved oxygen levels throughout the water column fig. 16b). These conditions persisted through the spring, but in early June the die-back of macroalgae resulted in a period of morning hypoxia and strong afternoon stratification (Fig. 16c). A phytoplankton bloom in the fall improved dissolved oxygen conditions, but the effects of the earlier die-back in macroalgae were still evident, as bottom waters remained anoxic $(<1 \mathrm{mg} / 1)$. 
Dissolved oxygen fluctuated greatly during the day in Pond A9, especially during May (Table 3). These fluctuations were during periods of tigh algal abundance and high diurnal variation in respiration and photosynthesis.

\section{Invertebrates}

The distribution of invertebrates in the salt ponds varied spatially and temporally with salinity, dissolved oxygen, and algal growth. Species richness declined progressively with salinity, especially above 35 ppt. Seventeen species were collected from Pond A9, thirteen from Pond Al0, five from Ponds All through $A 13$, and two from Pond A15 (Table 4). Seasonal community level changes in the two low salinity ponds (Ponds A9 and AlO) were pronounced (Table 5 and 6$)$, and were primarily related to variations in the relative and absolute abundance of phytoplankton and macroalgae. The substrate in all sia ponds was generally hard, often anoxic, and contained few invertebrates. Even the soft sediments, which were restricted to the dredged borrow pits, shorelines and remnant slough channels, contained few invertebrates because they were often covered with decaying vegetation and anoxic. In the low salinity ponds most of the benthic and epibenthic species relied on Enteromorpha as a substrate. Gammarid amphipods (i.e. 
Table 4: Invertebrate species distribution in six Alviso salt evaporation ponds, 1985-86.

\begin{tabular}{|c|c|c|c|c|}
\hline & \multicolumn{4}{|c|}{ Distribution } \\
\hline & A9 & $\underline{\text { AlO }}$ & All-Al3 & Al5 \\
\hline \multicolumn{5}{|l|}{ Conidaria } \\
\hline Actiniaria & $x$ & & & \\
\hline \multicolumn{5}{|l|}{ Hollusca } \\
\hline Germa germa & & $\mathrm{x}$ & & \\
\hline Ilyanassa obsoletus & $\mathbf{x}$ & $\mathrm{x}$ & & \\
\hline Tryonia imitator & $x$ & & & \\
\hline \multicolumn{5}{|l|}{ Annelida } \\
\hline Nereis succinea & $\mathrm{x}$ & $\mathrm{x}$ & & \\
\hline Polydora ligni & $\mathrm{x}$ & $\mathrm{x}$ & $\mathbf{x}$ & \\
\hline Tubificoides sp. & $\mathrm{x}$ & $\mathrm{x}$ & & \\
\hline \multicolumn{5}{|l|}{ Crustacea } \\
\hline Anisogammarus confervicolus & $\mathrm{x}$ & $\mathrm{x}$ & & \\
\hline Artemia salina & & $\mathrm{x}$ & $\mathrm{x}$ & $\mathrm{x}$ \\
\hline$\overline{\text { Balanus }} \overline{\text { sp. }}$ & & $\mathrm{x}$ & $\mathbf{x}$ & \\
\hline Copepoda & $\mathrm{x}$ & $\mathbf{x}$ & $\mathbf{x}$ & $\mathrm{x}$ \\
\hline Corophium sp. & $\mathrm{x}$ & $\mathrm{x}$ & $\mathbf{x}$ & \\
\hline Crangon spp. & $\mathrm{x}$ & $\mathrm{x}$ & & \\
\hline Hemigrapsus oregonensis & $\mathrm{x}$ & $\mathrm{x}$ & & \\
\hline Ostracoda & $\mathbf{x}$ & & & \\
\hline Palaemon macrodactylus & $\mathbf{x}$ & $\mathbf{x}$ & & \\
\hline Sphaeroma quoyana & $\mathrm{x}$ & & & \\
\hline \multicolumn{5}{|l|}{ Insecta } \\
\hline Trichocorixa reticulata & $x$ & $x$ & $x$ & \\
\hline
\end{tabular}


Table 5: Seasonal patterns of abundance for invertebrate species collected from Pond A9. $r=$ rare; $u=$ uncommon; $c=$ common;

$a=$ abundant.

Cridaria

Actiniaria

Annelida

Nereis succinea

Polydora ligni

Tubificoides sp.

\section{Mollusca}

Gemma germa

Ilyanassa obsoletus

Tryonia imitator

\section{Crustacea}

Anisogammarus confervicolus

Balanus sp.

Copepoda

Corophium sp.

Crangon spp.

Hemigrapsus oregonensis Ostracoda

Deiesmon macrojactyius

Sphaeroma quoyana

\section{Insecta}

Trichocorixa reticulata

\section{Distribution}

Fall Winter Spring Sumer Fall

$\begin{array}{lllll}- & - & \mathrm{C} & - & -\end{array}$

u u

- $\quad-$

$-$

$\mathrm{u}$

u $\quad$ r

c -

a a a

- -

c u

$\begin{array}{lll}c & - & - \\ c & - & u \\ - & - & c\end{array}$

a $r \quad r$

-

- $\quad-$

u

$\mathrm{u}$

c

-

c

c

-

u

u

u

-

u

c

$-$

$\begin{array}{lll}\mathrm{a} & \mathrm{r} & \mathrm{r} \\ \mathrm{c} & - & - \\ - & \mathrm{c} & \mathrm{c} \\ \mathrm{a} & \mathrm{r} & \mathbf{r} \\ \mathrm{u} & \mathrm{u} & \mathrm{u} \\ \mathrm{c} & \mathrm{r} & - \\ \mathrm{c} & - & - \\ \mathrm{c} & \mathrm{u} & \mathrm{u} \\ \mathrm{c} & \mathrm{c} & -\end{array}$


Table 6: Seasonal patterns of abundance for invertebrate species collected from Pond Alø. $r$ = rare; $u=$ uncommon; $c=$ conmon;

$a=$ abundant.

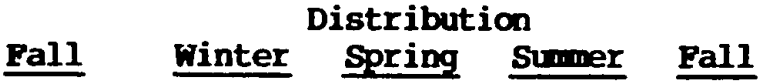

\section{Annelida}

Nereis succinea

Polycora ligni

Tubificoides SF.

-

\section{Mollusca}

Ilyanassa obsoletus

c

$\mathbf{u}$

C

$-$

$\mathbf{u}$

Crustacea

Anisogammarus confervicolus

Artemia salina

copepoda

Corophium sp.

Crangon spp.

Hemigrapsus oregonensis

Paiaenon macrodactylus

Insecta

Trichocorixa reticulata

-

-

- $\quad c$

c -

u u

u -

u

-

$-$

$c$

$c$

u

$\begin{array}{llll}- & -\end{array}$

c u -

c - -

u u u


Corophium sp. and Anisogammarus confervicolus), spionid polychaetes (Polydora ligni) and oligochaetes (Tubificoides sp.) were the most common invertebrates collected, although the molluscs Tryonia imitator and Gemma gemma, the polychaete Nereis succinea, and the decapods Crangon spp.. Palaemon macrodactylus, and Hemigrapsis oregonensis were also collected.

In Pond A9, species richness and abundance was highest in the late spring of 1986 (Table 5), when Enteromorpha covered as much as 60 percent of the pond surface. By the summer and early fall of 1986, diminished algal abundance and low dissolved oxygen levels reduced both species richness and densities. Amphipod densities (Corophium sp. and Anisogammarus confervicolus) which were high in the spring, declined sharply in the summer. The oliogchaete, Tubificoides sp., was most tolerant of poor water quality and was abundant throughout the spring, summer, and fall of 1986. In the late summer and fall, a phytoplankton bloom in Pond A9 was followed by an increase in copepod densities. Changes in the benthic community in Pond Alb were also related to fluctuations in water chernistry and algal abundance. Replacement of macroalgae by phytoplankton in the spring of 1986 was followed by a sharp decline in amphipod and polychaete densities in the early summer (Table 
6). Tubificoides sp. was abundant in late spring and summer in the decaying macroalgae. Both oligochaete and copepod densities declined in the fall with reduced phytoplankton abundance.

In the four high salinity ponds, the only common benthic and epibenthic invertebrate species collected were the polychaete polydora ligni and waterboatmen (Trichocorixa reticulata). Polydora was collected in shoreline sediments, at high densities in Ponds All, Al2, and Al3 at salinities as high as 65 ppt. Waterboatmen, which are epibenthic, but swim in the water column, were collected in low numbers in plankton surveys of all six ponds and at all salinities. When salinities dropped to sea water concentrations, other species were also collected from Ponds All through A15. Corophium amphipods were abundant in the late summer and fall of 1986 in Pond All near the intake from Pond Alø, while barnacles (Balanus sp.) were found attached in large numbers to the max-min thermometers in Ponds All, Al2, and Al3 during summer of 1986. Zooplankton was the most abundant invertebrate group in the high salinity ponds during all seasons, but was only a seasonally important component in the low salinity ponds. The most common zooplankton species were brine shrimp (Artemia salina) and calanoid copepods, including 


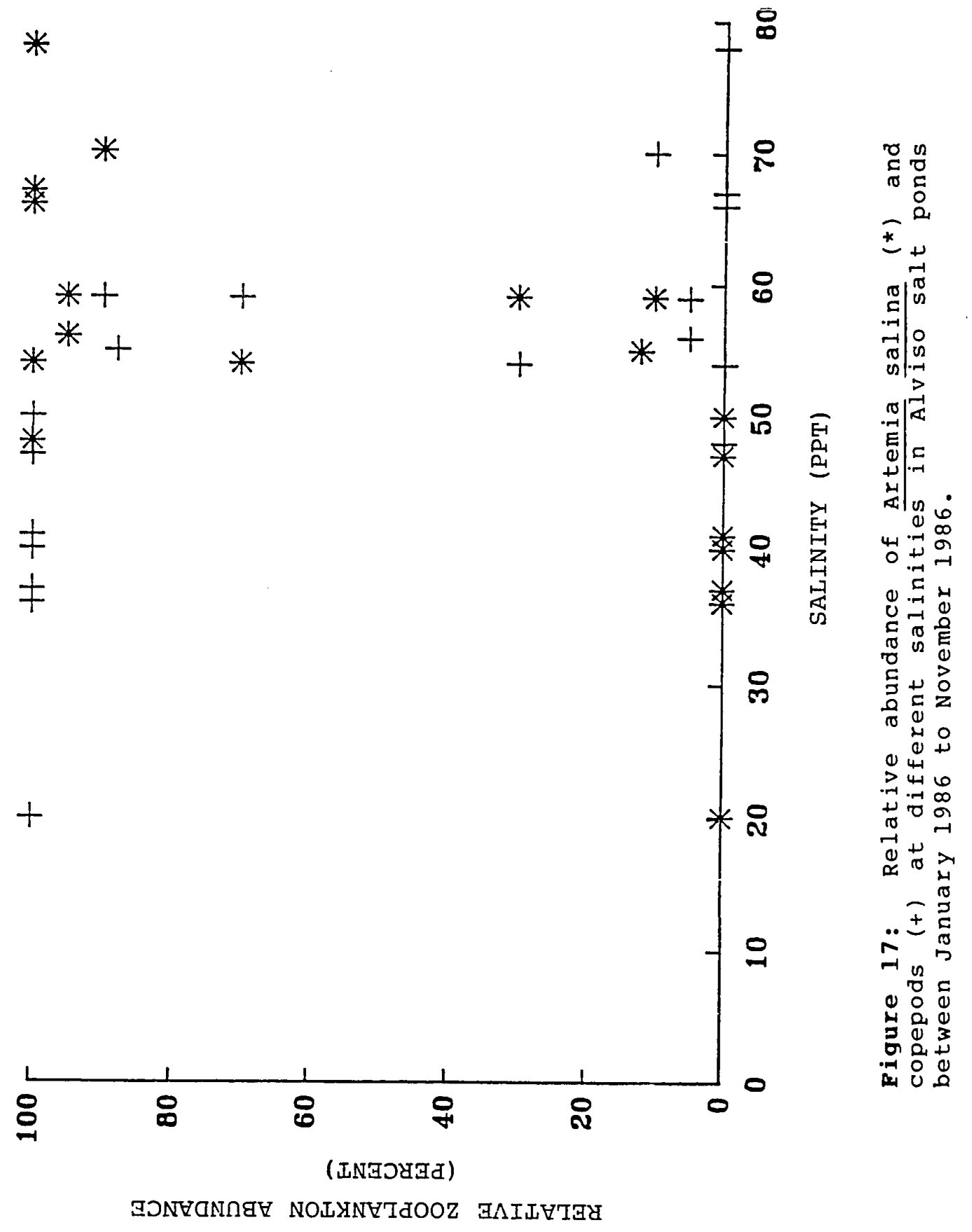




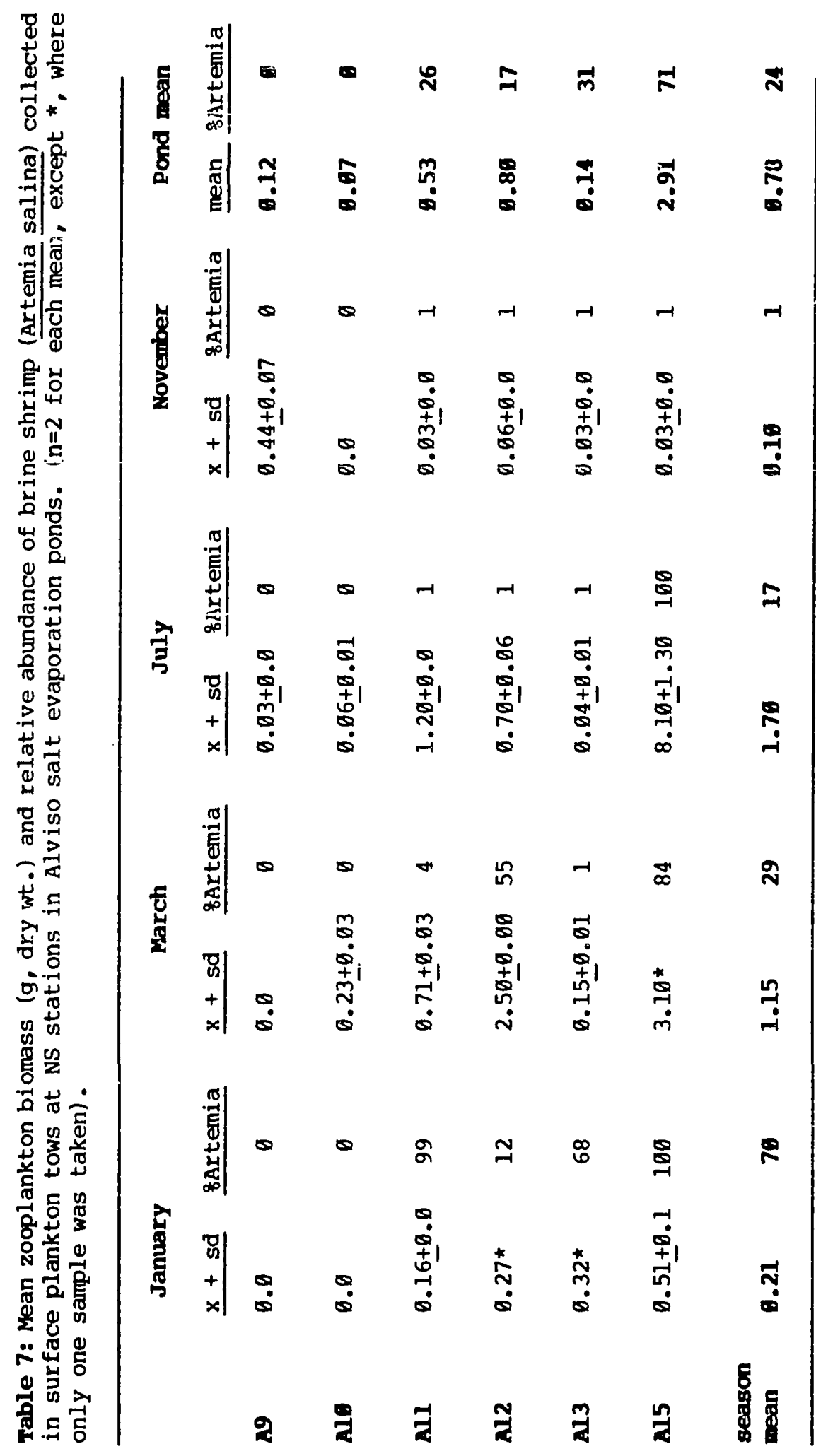


Pseudodiaptomus euryhalinus. The relative importance of these species varied with salinity (Fig. 17). At salinities greater than 60 ppt, brine shrimp were the predominant species, whereas at salinities below 45 ppt, copepods predominated. Between 45 and 60 ppt, neither species was predictably dominant.

Biomass estimates and species composition of zooplankton collected in the six salt ponds varied seasonaily (Tabie 7). Zooplankton densities were generally highest in the high salinity ponds. In the four high salinity ponds zooplankton were most abundant in July 1986 and were least abundant in the early fall of 1986 when secchi depths were high, reflecting low phytoplankton abundance. Copepods were collected in Alb in the winter of 1985-86 and increased through the spring and summer of 1986. In Pond A9, copepods were not collected in the spring of 1986, but became increasingly common in the late summer following a summer phytoplankton bloom.

Fish

Over 12,000 fish of fifteen species were collected in the six Alviso salt ponds between August 1985 and November 1986 (Table 8). Topsmelt and long-jawed mudsucker were the most widespread species and had spawning populations in all 
TABCE 8: Distribution and status of fish species collected in Alviso salt evaporation ponds, 1985-86. Pond (salinity range in ppt). $R=$ resident population; $S=$ seasonal population; $J=$ juvenile only.

\begin{tabular}{|c|c|c|c|c|c|c|}
\hline \multirow[b]{2}{*}{ Species } & \multicolumn{6}{|c|}{ POND } \\
\hline & $\begin{array}{c}\text { A9 } \\
(22-40) \\
\end{array}$ & $\begin{array}{c}\text { Alg } \\
(22-4 \theta) \\
\end{array}$ & $\begin{array}{c}\text { All } \\
(23-84) \\
\end{array}$ & $\begin{array}{c}A 12 \\
(30-66) \\
\end{array}$ & $\begin{array}{r}\text { Al3 } \\
(35-67) \\
\end{array}$ & $\begin{array}{r}\mathrm{Al5} \\
(49-83) \\
\end{array}$ \\
\hline \multicolumn{7}{|l|}{ Topsmelt } \\
\hline Longjawed mudsucker & $\mathbf{R}$ & $\mathbf{R}$ & $\mathbf{R}$ & $\mathbf{R}$ & $\mathbf{R}$ & $\mathbf{R}$ \\
\hline Threespine stickleback & $\mathbf{R}$ & $\mathbf{R}$ & $\mathbf{R}$ & $\mathbf{R}$ & $\mathbf{R}$ & $\mathbf{R}$ \\
\hline Rai (Gasterosteus $\frac{\text { acuieatus) }}{\text { acter killifish }}$ & $\mathbf{R}$ & $\mathbf{R}$ & 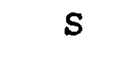 & $\mathbf{S}$ & $\mathbf{S}$ & $s$ \\
\hline Yellowfin goby & $\mathbf{R}$ & $\mathbf{R}$ & $s$ & $\mathbf{s}$ & $\mathbf{S}$ & $s$ \\
\hline Pacific staghorn $\frac{\text { flavimanus) }}{\text { sculpin }}$ & 5) $R$ & $\mathbf{R}$ & $\mathbf{S}$ & s & $\mathbf{S}$ & s \\
\hline Bat (Leptocottus asmatus) & $\mathbf{R}$ & $\mathbf{R}$ & SJ & SJ & SJ & SJ \\
\hline Leopard shark & $s$ & S & & & & \\
\hline (Triakis semifasciata) & $S$ & $S$ & & & & \\
\hline Bay (Engraulis mordax) & $s$ & $s$ & & & & \\
\hline Bay goby & 5) $S$ & $\mathbf{S}$ & & & & \\
\hline (Lepidogobius lepidus) & $S$ & $\mathbf{S}$ & & & & \\
\hline $\begin{array}{l}\text { (Cymatogaster aggregata) } \\
\text { Starry floumder }\end{array}$ & $S$ & s & & & & \\
\hline Striped bass & s & s & & & & \\
\hline English sole & $s$ & & & & & \\
\hline (Parophrys vetulus) & S & & & & & \\
\hline
\end{tabular}


six ponds. Yellowf in goby (Acanthogobius flavimanus), three-spined stickleback (Gasterosteus aculeatus), rainwater killifish (Lucania parva), and Pacific staghorn sculpin (Leptocottus armatus) also were present in all six ponds, but regularly reproduced only in the low salinity ponds (Pond $A 9$ and $A 1 \emptyset$ ). The remaining $\bar{n}$ ine species occurred irregularly as immigrants from the Bay and were found only in salinities below $35 \mathrm{ppt}$. Several of these non-resident species were present in Ponds $A 9$ and $A l \emptyset$ until the summer of 1986, but disappeared when dissolved oxygen conditions deteriorated.

Seasonal changes in species composition within the high salinity ponds were usually related to salinity. Most species were not found at salinities above $35-40$ ppt. In the low salinity ponds, species composition also changed, but in response to poor summer water quality.

\section{Topsmelt}

Seasonal topsmelt gill net results for the six ponds are shown in Table 9. Topsmelt were collected in all ponds to salinities as high as 85 ppt, whereas gravid females and young fish were collected only to $70-75 \mathrm{ppt}$. There were similar strong seasonal changes in catch rates in both high and low salinity ponds, with catch per unit effort in 1986 


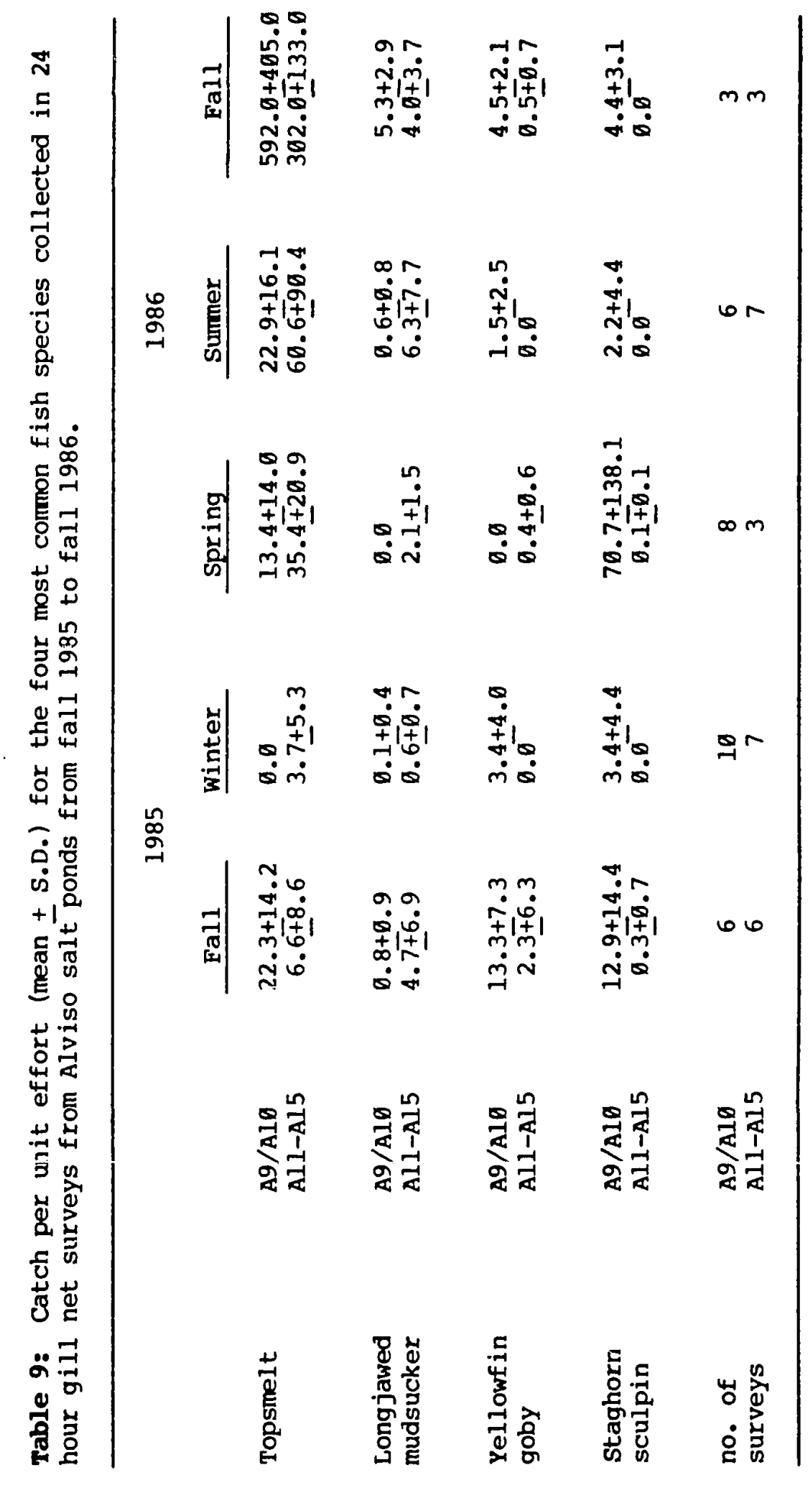


increasing from winter through the following fail. Mean lengths of fish collected by gill net increased from spring through summer 1986 and decreased again in fall 1986 (Table 10). Mean size of topsmelt in high salinity ponds was less than in the low salinity ponds in all seasons (Table ll). The spawning season of topsmelt in the salt ponds was determined from $f$ ish captured in Ponds All to Al5. These fish were less likely to include immigrants from san Francisco Bay than topsmelt captured in the two low salinity ponds (Ponds $A 9$ and $A 10$ ). Based on measurements of gonad volume and egg size in fish collected from the high salinity ponas, the spawning season for topsmelt in the ponds extended from February through september, with a peak between March and July (Table 11). Several fish collected in February contained a small number of mature eggs, and the proportion increased through July. Fish containing ripe or mature eggs were still collected as late as september, but october fish contained only immature eggs. Larval and juvenile topsmelt $(<3 \emptyset \mathrm{mm})$ were collected in the months of March and August. However, larval fish were also collected in December 1985 and January 1986, suggesting that the spawning season may have been more protracted than the gonad data indicated.

Female topsmelt reached sexual maturity at 


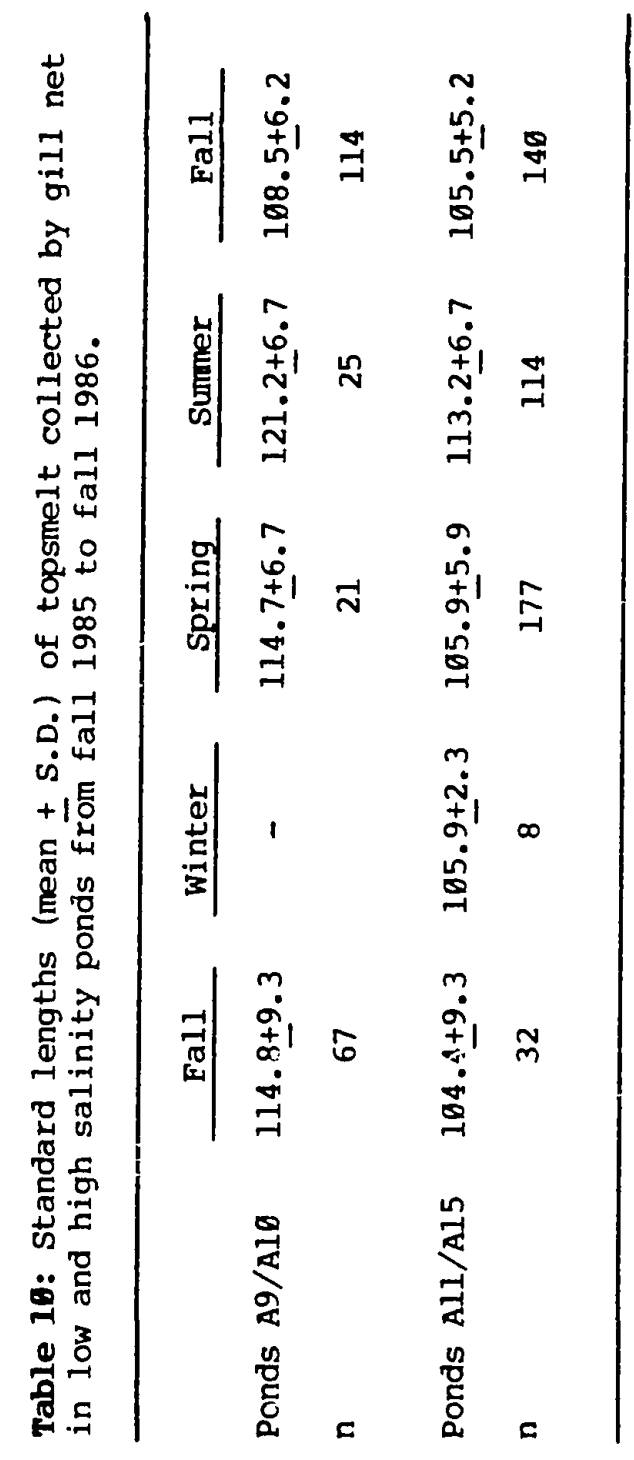




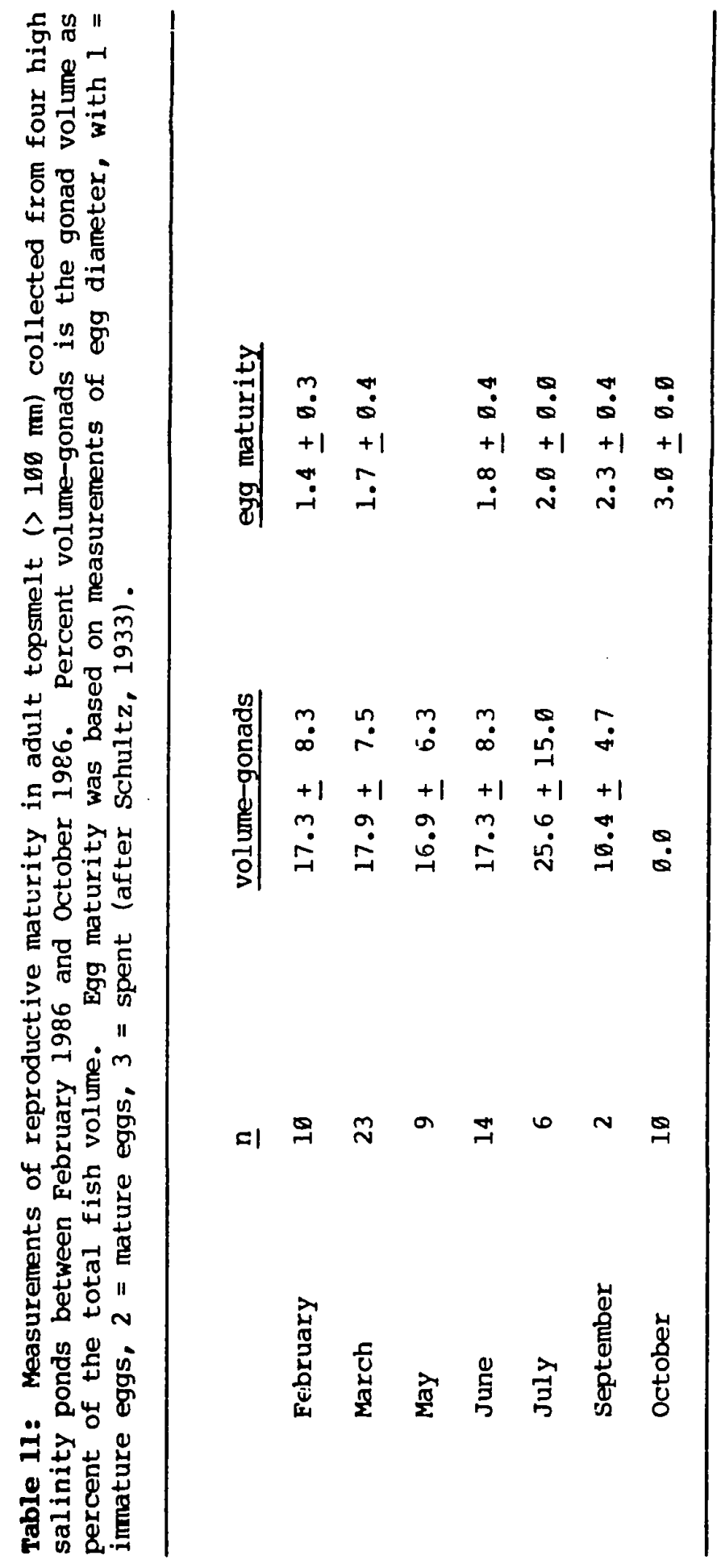


approximately $10 \emptyset-110 \mathrm{~mm} \mathrm{SL}$, while males matured at approximately $90-10 \emptyset \mathrm{mm}$. The life-span of the resident topsmelt, based on length frequency data and scale aging, was less than 2 years. Fish hatched in the spring grew to 90-100 mm by late fall, and some may have spawned by the end of their first year. By the spring of their second year all of the fish were mature. At the end of their second summer topsmelt attained lengths of $120-130 \mathrm{~mm}$. No topsmelt longer than $130 \mathrm{~mm}$ were collected in the high salinity ponds. Food habits of topsmelt varied substantially with pond and season (Table 12), but in general food selection reflected the relative abundance of available prey. In the high salinity ponds topsmelt consumed brine shrimp, waterboatmen, and copepods (Table 12). Waterboatmen and brine shrimp were the principal prey during periods when salinities were high (i.e. the wincor and spring), and copepods were the principal prey when salinities were low (i.e. summer and fall). Benthic species, such as polydora ligni and brine fly larvae, were not found in sampled stomachs. In the low salinity ponds, the diet of topsmelt varied with the changes in the structure of the algal and invertebrate communities. Gammarid amphipods (i.e. Corophium sp.) were the primary prey during macroalgal blooms, whereas planktonic algae and copepods were fed on 
Table 12: Diet of topsmelt (Atherinops affinis) from four high salinity ponds, and the relative availability of prey species (prey av.) determined from plankton surveys.

\begin{tabular}{|c|c|c|c|c|c|c|c|c|}
\hline & \multicolumn{4}{|c|}{ Winter $1985-86, n=23$} & \multicolumn{4}{|c|}{ Spring $1986, n=13$} \\
\hline & \&freg & inumber & \&vol & $\begin{array}{c}\text { prey } \\
\text { av. }\end{array}$ & \&freg & inumber & 8vol & $\begin{array}{c}\text { prey } \\
\text { av. }\end{array}$ \\
\hline Brine shrimp & 87 & 76 & 76 & 100 & 55 & 44 & 33 & 66 \\
\hline Copepoda & $\emptyset$ & $\emptyset$ & $\varnothing$ & Ø & 19 & 17 & 15 & 33 \\
\hline Waterboatmen & 21 & 24 & 24 & - & 74 & 39 & 38 & - \\
\hline \multicolumn{5}{|c|}{ Mean std. length (im) } & \multicolumn{4}{|c|}{93} \\
\hline & \multicolumn{4}{|c|}{ Summer $1986, n=22$} & \multicolumn{4}{|c|}{ Fall 1986, $\mathrm{n}=11$} \\
\hline & \multicolumn{4}{|r|}{ prey } & \&freg & \&number & \&vol & $\begin{array}{c}\text { prey } \\
\text { av. }\end{array}$ \\
\hline Brine shrimp & 68 & 26 & 39 & 25 & 36 & 3 & 8 & 1 \\
\hline Copepoda & 68 & 56 & 42 & 75 & 82. & 86 & 67 & 99 \\
\hline Waterboatmen & 42 & 15 & 18 & - & 82 & 11 & 17 & - \\
\hline \multicolumn{2}{|c|}{ Mean std. length (m) } & 92 & & & \multicolumn{4}{|c|}{99} \\
\hline
\end{tabular}


during phytoplankton blooms.

\section{Longjawed mudsucker}

Longjawed mudsuckers were collected in all six ponds at all salinities. Like topsmelt, mudsucker experienced seasonal variations in abundance (Table 9). Highest longjawed mudsucker catches were during the summer and fall, while very few individuals were collected during the winter. Gill net catches were usually greater in the high salinity ponds than in the low salinity ponds, except for the fall of 1986 (Table 9).

The spawning season for longjawed mudsucker, based upon length frequency distritutions of $\mathrm{fish}$ collected from ponds All to Al5, was estimated to extend from November through June. Most reproduction appeared to be concentrated in February-March. Larval fish $(\langle 10 \mathrm{~mm})$ were first collected in early December 1985, but highest densities were found in March 1986 in Ponds Al2 and Al3. Longjawed mudsucker larvae were collected in every pond and at salinities up to $70 \mathrm{ppt}$. Longjawed mudsucker grew to approximately $8 \theta-100 \mathrm{~mm}$ SL in their first year, and up to $i 20-140 \mathrm{~mm}$ by their second year. One year old $f$ ish had mature gonads. Very few individuals survived past their first year, and no fish older than two years were collected in the ponds. 
Table 13: Diet of longjawed miủsucker (Gillichthys mirabilis) from four high salinity ponds, and the reiative availability of prey species (prey av.) determined from plankton surveys.

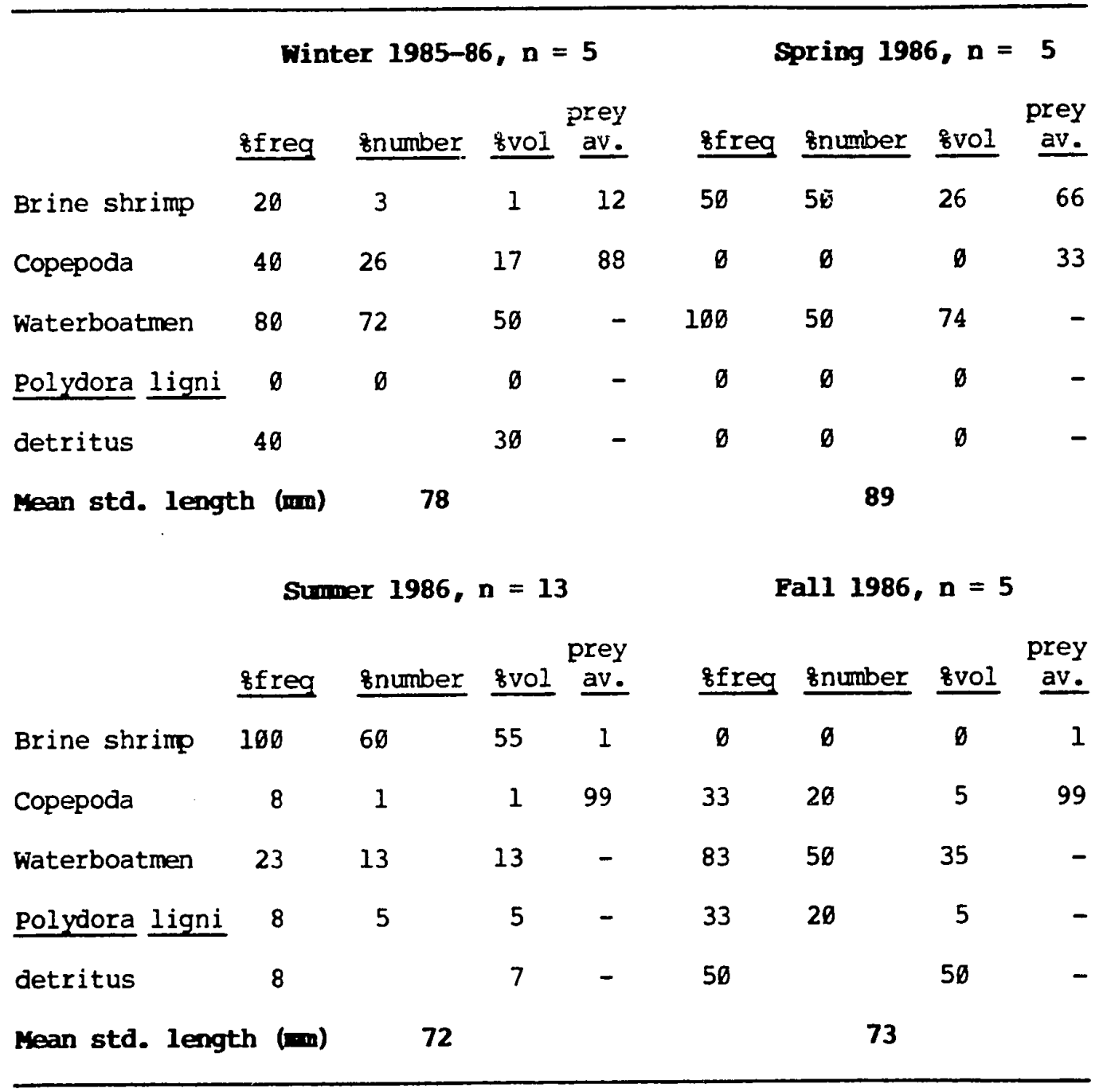


A limited sample of longjawed mudsuckers $(n=5)$

collected from the low salinity ponds were found to have fed on polychaetes and amphipods. In the high salinity ponds $(n=29)$, they fed primarily on waterboatmen and brine shrimp (Table 13). Soft bodied species, such as polydora ligni, were rare in stomachs, possibly reflecting their easier digestion. Copepods, despite their small size, were an important winter food item for adult mudsuckers. However, they were not utilized in spring, when brine shrimp were relatively abundant (Table 13 ).

\section{Yellowfin goby}

Yellowfin goby were commonly collected in Ponds A9 and Ald during the fall of 1985 and 1986 , but decreased in numbers during the winter and spring of 1986 (Table 9). Yellowfin goby were collected in the higher salinity ponds, including one adult in Pond Al3 during February 1986 at a salinity of 50 ppt, but they appeared to be rare in these ponds. Gravid females were collected in late winter 1986 in Pond A9, and larval goby were collected in early spring from Pond A9. Many of the individuals using the ponds were probably immigrants from the Bay, since numbers were low except for periods when the ponds were open to the Bay (June to November 1986). The ages of the yellowfin goby collected 
ranged from $\emptyset$ to 2 years old. No fish older than 2 years, or longer than $160 \mathrm{~mm} \mathrm{SL}$, were collected. Yellowfin goby was the only species collected that fed heavily on polychaete and oligochaete worms in the low salinity ponds. Their diet also included most other invertebrates and even killifish. Yellowfin goby examined from the high salinity ponds $(n=4)$, contained brine shrimp and juvenile yellowfin goby.

\section{Rainwater killifish}

Rainwater killifish appearea to be permanent residents in the low salinity Ponds $A 9$ and $A 10$, and at least seasonal residents in the high salinity ponds. They were found in salinities as high as 80 ppt, but were most abundant in beds of Enteromorpha in Ponds $A 9$ and Alø. Along with threespined stickleback, they survived in Pond $A 9$ in the summer of 1986 when low dissolved oxygens and food densities severely reduced or eliminated populations of other fish species from the pond.

The presence of larval killifish in Pond Al2 and Al3 during March 1986 (the apparent spawning peak) indicated spawning is possible at salinities of 55 ppt. The few killifish examined $(n=7)$ fed exclusively on crustaceans. At low salinities, they fed on amphipods, while at higher 
salinities they fed on brine shrimp and copepods.

\section{Three-spined stickleback}

Three-spined stickleback were permanent residents in Ponds $A 9$ and $A 10$, and seasonal residents in the higher salinity ponds at salinities of up to 65 ppt. Their abundance was highest in the low salinity ponds and progressively decreased in the high salinity ponds. Although juvenile and adult three-spined stickleback were collected in the winter and spring in most ponds, they were most abundant after early June when Bay water was introduced into pond $A 9$.

The diet of three-spined sickleback $(n=7)$ was very similar to the killifish. in the low salinity ponds stickleback fed on the amphipods inhabiting the algal mats, whereas in the high salinity ponds they fed on brine shrimp and copepods.

\section{Staghorn sculpin}

Both adult and juvenile staghorn sculpin were present in the ponds. Juvenile fish $(10-15 \mathrm{~mm})$ were first collected by December 1985 and may have immigrated from the Bay or hatched within the ponds. By late spring staghorn sculpin, less than $100 \mathrm{~mm} \mathrm{SL}$, were the most abundant species 
collected in Ponds $A 9$ and Al0. Although always most abundant in these ponds, juvenile sculpin were tolerant of high salinities and actively dispersed to all ponds (Table 9). They were collected from Pond Al5 in late spring 1986 when the salinity was 65 ppt. However, by late summer they had disappeared from the high salinity ponds despite the fact that pond salinities dropped. They also became less numerous in summer gill net surveys of low salinity ponds (Ponds $A 9$ and $A 10$ ), before increasing again in the fall. The diets of adult $(n=5)$ and juvenile staghorn sculpin $(n=21)$ in the salt ponds were quite distinct. Adults fed almost exclusively on large prey (i.e. killifish, gobies, and Crangon spp.). Juvenile fish preyed on much smaller food items, including polychaetes and large amphipods in the low salinity ponds, and brine shrimp in the high salinity ponds.

\section{Non-residents}

Eight species of non-residents were present in Pond A9 in the fall of 1985, but only juvenile leopard shark (Triakis semifasciata), adult bay pipefish (syngnathus leptorhynchus), shiner surfperch (Cymatogaster aggregata), and juvenile starry flounder (Platichthys stellatus) were collected through late spring of 1986. Adult northern 
anchovy (Enraulis mordax) were common in fall 1985 but

absent during the remainder of the study. Juvenile english

sole (Parophrys vetulus), adult bay goby (Lepidogobius

lepidus), and juvenile bat ray (Myliobatis californica) were

occasionally collected in fall 1985. Juvenile striped bass

(Morone saxitalis) ( $150 \mathrm{~mm} \mathrm{SL}$ ) were collected only in fall

1986. None of these species was common in Pond Al0, and

none was collected in either Pond $A 9$ or $A 10$ during the

summer of 1986 when dissolved oxygen levels were severely

depressed. 


\section{DIScussion}

Environmental conditions in the low to moderate salinity (20-85 ppt) salt evaporation ponds of south san Francisco Bay differ substantially from those in the surrounding Bay environment. Although seasonal temperature ranges in these ponds are similar to those of the south Bay (Aplin, 1967), the ponds show much greater seasonal and year to year variability in dissolved oxygen, $\mathrm{pH}$, and salinity. Two types of pond environments exist among the six salt ponds studied. These include the generally hyposaline or brackish water habitats of Ponds $A 9$ and $A 10(2 \theta-40$ ppt) which supported many of the local South Bay fish species. Factors which influenced community structure in these ponds included immigration from the Bay, seasonal fluctuations in relative and absolute abundance of phytoplankton and macroalgae, dissolved oxygen levels, and to a lessej: degree, salinity. The generally hypersaline habitats of ponds All through Al5 provided the other habitat type. The high salinity ponds were very productive for those few species of fish (i.e. topsmelt and mudsucker) and invertebrates (i.e. brine shrimp) which could surfive in them, but they showed strong seasonal fluctuations in productivity and composition of less tolerant species. 
Within the low salinity ponds (Ponds A9 and AlO) salinity was not generally limiting since the range of salinities in these ponds overlaps with the range that estuarine organisms are exposed to in the South Bay (Aplin, 1967. Conomos, 1979). Immigration from the South Bay into these ponds is limited to those species of $f$ ish found in the surrounding Bay during the months when the ponds are open to tidal flow, generally May through october. In the present study, fifteen fish species appeared to enter the ponds from the Bay, and eight to ten of these appeared to sustain populations in the ponds only with this immigration. In Carpelan's earlier study (1957), he reported few migrants, apparently because South Bay water quality was quite poor then and South Bay fish rare (Regional water pollution Control Board, 1957).

The green macroalga, Enteromorpha sp., was an important focd resource and micro-habitat for both fish and their invertebrate prey in the low salinity salt ponds. However, the die-back of macroalgae during the winter and spring of 1986 brought on widespread loss or reduction of shelter and food. These losses and low dissolved oxygen levels produced by the decomposing algae greatly reduced invertebrate and fish abundances and delayed their recovery until late summer and fall. 
The mechanisms for the changes in the source of primary productivity in Ponds $A 9$ and $A I B$ are not fully understood, although it does appear that in each pond the causes were different. In Pond Alø, the late winter 1986 die-back of macroalgae coincided with the influx of turbid, hypersaline water from Pond All. Increased salinity or plankton-derived turbidity may have suppressed macroalgal production. Bioturbidity and nutrient uptake by the phytoplankton appeared to have excluded Enteromorpha from the pond for most of the following summer. In Pond A9, the summer die-back of macroalgae coincided with high pH and salinity levels that peaked at 10.9 and 35 ppt, respectively. The rate of photosynthesis by Enteromorpha diminishes at higher salinities (Josselyn and Shellem, 1982) and at high pH (Jollife and Treguna, 1970). At high pH the primary source of carbon available to plants is as $\mathrm{HCO}_{3}$ and $\mathrm{CO}_{3}$ (olausson, 1980). Enteromorpha can utilize neither as a carbon source (Howe, 1937; Jollife and Treguna, 1970). Increased turbidity in Pond $A 9$ and $A 10$ may also have been a factor in suppressing macroalgal growth.

Blooms of Enteromorpha are most common in shallow, warm, nutrient rich and moderately saline (10-20 ppt) waters of San Francisco Bay (Josselyn and West, 1985). However, pond management practices, and the non-tidal nature of the 
salt pond habitats, can turn seasonal cycles into annual crises. In tidal systems, decomposing algae can be washed off mudflats by the tides, and $f$ ish can avoid areas of low dissolved oxygen. In the ponds, decomposing algae accumulates on the bottom and $f$ ish are trapped in areas of oxygen depletion and invertebrate scarcity. Salt pond fish communities may annually be subjected to dissolved oxygen and food source stresses of the type which caused the community level changes observed in Ponds $A 9$ and $A l 0$ in 1986. However, the severity of these changes may vary annually. Because of this variation, the species composition of fishes in these low salinity ponds is also variable. The makeup of the fish community will reflect the colonizing species pool found in the surrounding Bay during the recovery.

Macroalgae were rarely found in the high salinity ponds and were never abundant, apparently because of high salinities and high bio-turbidities. Macroalgae were only present in Ponds $A l 1$ and Al2 when salinities were low (23-30 ppt) and were confined to the shallow pond edges where they could not be shaded by phytoplankton. The absence of macroalgae eliminated the episodic crashes in primary productivity that occurred in the low salinity ponds, where macroalgae were a ciominant source of production. 
In this study phytoplankton abundance was strongly related to salinity. Changes in salinity, especially in the 35-40 ppt range, led to reduced algal abundance in the ponds. Although these changes occurred in the summer, it is not likely that high water temperatures caused these declines. Pond temperatures are well within the tolerance range of pond phytoplankton (Gibor, 1956). The salinity range closely matches the range where Gibor (1956) (Fig. 18) found changes in relative growth rates of salt pond phytoplankton species. This suggests that the reduced production may be due to species shifts in the phytoplankton community.

Hypoxia of subsurface waters was encountered in both the low and high salinity ponds. Dissolved oxygen stratification often forced distributional changes in the fish and invertebrate species. During those periods of extreme hypoxia in the ponds (i.e., summer) fish and invertebrates were forced towards the oxygenated surface layer, where they became much more vulnerable to avian predation. Feeding aggregations in the ponds by terns, herons, pelicans, and cormorants were observed almost exclusively during the summer.

The absence of brine shrimp from salinities below 50 ppt may reflect the efficiency of $\mathrm{fish}$ predators, 


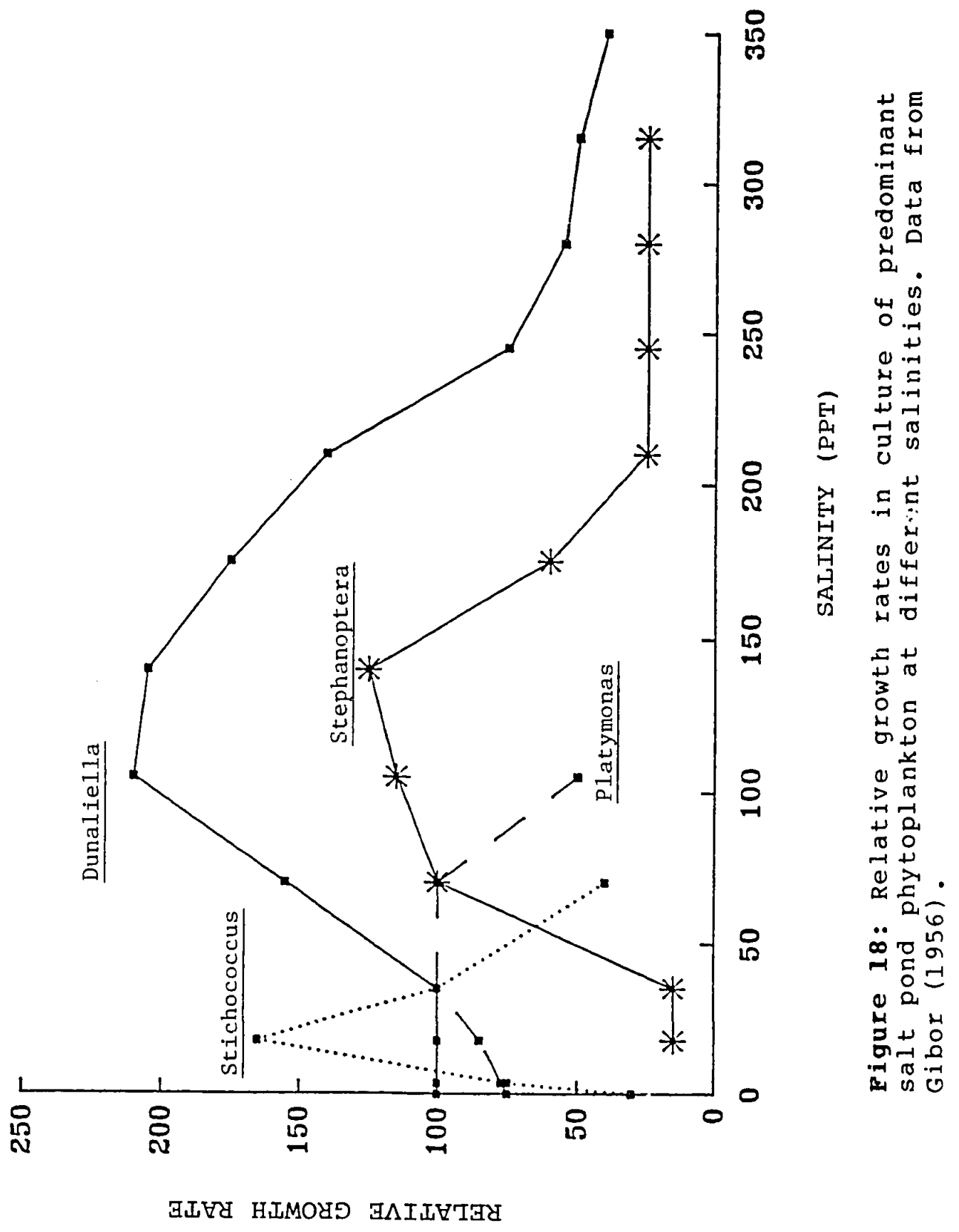


competition with other zooplankton, or the scarcity of a suitable phytoplankton food source. In this study phytoplankton abundance was often reduced at low salinities. In addition, the most common phytoplankton of salinities below 40 ppt, Sticchococcus bacillaris (Carpelan, 1957), can not be digested by brine shrimp (Carpelan, 1964).

The periodic environmental stresses found in the salt ponds, which lead to dramatic changes in species composition in both low and high salinity pond habitats, favor fish species which are small, short-lived, opportunistic, and early spawners. Non-resident species included some adults, but most were represented by juveniles. These species are handicapped by an inability of certain life stages to cope with prevailing pond conditions or with periods of poor water quality. Juvenile fish may generally be more euryhaline than large $f$ ish, possibly because of changes in metabolic rates that occur with age (Kinne, 1964).

Most salt pond $f$ ish species spawned in their first or second year and did not survive longer than two years in the ponds. Although topsmelt, yellowfin goby, and mudsucker can live more than two years in San Francisco Bay (Schultz, 1933; Armor and Herrgesel1, 1985), adults of these species were not abundant by the winter of their second year in the ponds. This suggests that late fall and winter may be 
stressful to post-spawning adults. The same level of stress does not develop for juvenile fish, since they survive the winter to siawn in the subsequent spring and summer. However, scales of juvenile topsmelt showed growth reduction during their first summer and fall.

The opportunistic diet of salt pond fishes may be a necessary strategy in the ponds. Topsmelt, for example, feed predominantly on algae in estuaries (Moyle, 1976), but in the ponds, where seasonal and spatial variability in prey resources was common, the topsmelt diet included fish, amphipods, copepods, and brine shrimp. 


\section{CONCLOSIONS AND RBCOMBNDATIONS}

Management of Alviso salt ponds for salt production has produced locally unique habitats, with fluctuating salinities, relatively stable water levels, and periods of low dissolved oxygen and high $\mathrm{pH}$. These habitats are heavily utilized by many invertebrates, $f$ ish, and birds that prey on them. However, the rapid movement of water among ponds, and the seasonal closure to tidal action, which are characteristic of present salt pond management, reduce the value of the ponds as habitats. Rapid movement of water, and the resulting salinity changes, especially in the $39-40$ ppt range, appear to trigger major shifts in absolute and relative abundance of algae, invertebrates, and fish, Closure to tidal flow reduces water circulation through the ponds and can result in high $\mathrm{pH}$ and die-back of macroalgae in low salinity ponds. Seasonal closures to tidal flow also prevents movement of fishes from the Bay into the ponds, and movement among the different ponds.

Efforts to improve the low to moderate salinity salt ponds (2ø-85 ppt) as wildlife habitats, without interfering with salt production; should focus on controlling dramatic seasonal changes in productivity and species composition found under current operations. These changes appeared to 
be associated with poor water quality and low primary productivity, which in turn were by-products of salt management practices. This study has shown that macroalgae is a critical resource for $f$ ish and invertebrates in the low salinity ponds. Therefore, it is important that conditions which favor the growth of macroalgae are encouraged. While environmental conditions in some ponds were generally suitable for macroalgal growth, especially when salinity was below sea water concentrations and $\mathrm{pH}$ was below 9.0 , conditions often became unfavorable for macroalgae. Widespread die-backs of macroalgae were associated with high $\mathrm{pH}$ and high salinity, and appeared to be the product of seasonal changes in water circulation. Although the closure of the intake pond to tidal flow during the winter and spring maintains salinities at levels necessary for salt harvest, it deprives the pond of low salinity, low pH water, and the circulation which may be necessary to reduce the probability of large scale die-backs of pond macroalgae. Management of low salinity ponds for wildife may require opening the ponds to tidal flow in spring before salinity and $\mathrm{pH}$ concentrations in the ponds approach levels potentially detrimental to algal productivity. Means of providing for movement of $f$ ish from the ponds to the Bay should be investigated. Many non-resident $f$ ish species in 
the ponds are transients in the south Bay and must move down the estuary to complete their life cycle (i.e., northern anchovy, shiner surfperch, and striped bass), but are unable to migrate from the ponds under present flow conditions. In this study, seasonal changes in salinity within the high salinity ponds (Ponds All to Al5) often produced rapid and dramatic shifts in $f$ ish, invertebrate, and algal species composition and productivity. These changes in salinity may be inevitable under present management conditions, but are unnecessary if the ponds are managed exclusively for wildife. Salinities in these ponds should be maintained above 40-45 ppt to provide conditions suitable for brine shrimp. If habitat for $f$ ish is desired the ponds should be kept below 75 ppt.

If salt production is abandoned, many salt ponds could be reclaimed as tidal wetlands, but some might be retained and managed to provide moderate salinity (40-150 ppt) habitat for brine shrimp and the $f$ ish and birds that have come to depend on them. 


\section{LITERATURE CITBD}

Anderson, w. 1970. A preliminary study of the relationship of salt ponds to wildife in south San Francisco Bay. Cal. Fish and Game 56: 240-252.

Aplin J.A. 1967. Biological Survey of San Francisco Bay, 1963-66. Cal. Fish and Game Marine Res. 67-4. 131 pp.

Armor, C. and P.L. Herrgesel1. 1985. Distribution and abundance of $f$ ishes in the San Francisco Bay Estuary between 1980 and 1982. Hydrobiologia. 129: 211-227.

Berthelemy-Okazaki, N. 1986. Environmental, biochemical and genetic factors regulating oviparity in Artemia. University of California, Davis, 197 pp. Ph.D. Dissertation.

Baker, M.S. 1966. Autecology of Artemia: Factors influencing hemoglobin synthesis and cyst production. San Francisco state College, 117 pp. M.A. Thesis.

California state Regional Water Pollution Control Board. Report on Pollution and Nuisance Conditions in San Francisco Bay South of Dumbarton Highway Bridge. 1957. Available from: Water Resources Library, University of California, Berkeley.

Carpelan, L.H. 195b. Tolerance of San Francisco Bay topsmelt (Atherinops affinis) to conditions in salt producing ponds bordering San Francisco Bay. Cal. Fish and Game 41: 279-285.

Carpelan, L.H. 1557. Hydrobiology of Alviso salt ponds. Ecology $38(3): 375-390$.

Carpelan, L.H. 1964. Effects of salinity on algal distribution. Ecology $45(1): 70-77$.

Copeland, B.J. 1967. Environmental Characteristics of Hypersaline Lagoons. Cont. Mar. Sci. Univ. Tex. 12: 208-229.

Gibor, A. 1956. Culture of brine algae. Biol Bull. 111: $223-229$.

Gill, R. 1977. Breeding avifauna of South San Francisco Bay estuary. West. Birds 8: 1-12. 
Gunther, G. 1961. Some relations of estuarine organisms to salinity. Limn. Ocean. 6: 182-190.

Howard, J.A. 1983. Feeding ecology of the Ruddy Duck on the San Francisco Bay vational wildlife Refuge. San Jose State University. 60 pp. M.A. Thesis.

Howe, N.H. 1937. The ecology of a saline lagoon in southeast Essex. J. Linn. Soc. Lond. Zool. 40: 383-446.

Jollife, E.A. and E.B. Treguna. 1970. Studies of $\mathrm{HCO}_{3}{ }^{-}$ion uptake during photosynthesis in benthic marine algae. Phycologia $9(3 / 4): 293-303$.

Josselyn, M.A. 1983. The Ecoloyy of San Erancisco Bay Tidal Marshes: A Community Profile. U.S. Fish and Wildlife Service Division of Biological Services, Washington D.C. FWS/OBS-83-23. 102 pp.

Josselyn, N.A. and J.A. West. 1985. The distribution and temporal dynamics of the estuarine macroalgal community of Sän Francisco Bay. Hydrobiologia 129: 139-152.

Josselyn, M.A. and B.Il. Shellem. 1982. Physiological ecology of Enteromorpha clathrata (Roth) on a saltmarsh mudflat. Bot. Mar. 25: 541-549.

Kinne, 0. 1964. The effects of temperature and salinity on marine and brackish water animals. Oceanogr. Mar. Biol. Ann. Rev. 2: 281-339

Moyle, P.B. 1976. Inland Fishes of California. Univ. Cal. press, Berkeiey. pp. 276-277.

Nichols, F.H., J.E. Cloern, S.N. Luoma and D.H. Peterson. 1986. The modification of an estuary. Science 231: $567-73$.

Olausson, E. 1980. The carbon dioxide-calcium carbonate system in estuaries. in Chemistry and Biogeochemistry of Estuaries. Olausson and Cato, J. Eds. J. Wiley and Sons, Chichester. pp. 297-305.

Schultz, L.P. 1933. The age and growth of A. affinis oregoniz (Jordan and Snyder) and other subspecies of Baysmelt along the Pacific coast of the United States. Univ. of wash. Pub. in Biology 2: 47-96 
Stenzel, L.E. and G.W. Page. 1988. Results of the 16-18 April 1988 shorebird census of San Francisco and San Pablo Bays. Point Reyes Bird observatory, unpublished report. $18 \mathrm{pp}$.

Swarth, C.w., C. Akagi and P. Metropoulus. 1982. The distribution patterns and ecology of waterbirds using Coyote Hills salt ponds. unpubl. U.S. Fish and wildlife Service. San Francisco Bay tiational Wildife Refuge. 75 pp.

Takekawa, J. Y., D.S. Gilmer, C.M. Marn, H.M. Olhendorf, L.A. Accurso and J.E. Takekawa. 1988. Abundance, distribution and habitat use of wintering waterfowl in the San Francisco Bay ecosystem, 1987-1988. U.S. Fish and Wildlife Service Draft report. 42 pp. 